\title{
Okoliczności powstania oraz przejawy dzialalności religijnej i kulturowej jezuitów w Plocku w XVII i XVIII wieku ${ }^{1}$
}

\begin{abstract}
The origins and manifestation of religious and cultural activities of Jesuits in Płock $\left(17^{\text {th }}\right.$ and $18^{\text {th }}$ centuries)

The goal of this article is to present the circumstances accompanying the establishment of the Jesuit collegium in Płock. The author analyses the economic, political and cultural bases of the foundation as well as the role played in this venture by bishops Andrzej Noskowski and Marcin Szyszkowski. Finally, in 1616 the Jesuit foundation in Płock was approved by the Polish Parliament.

The article includes a description of the working methods employed by the Jesuit teachers, the curricula, as well as the extra-curricular forms of affecting the local community of the Jesuit Society Collegium - the Sodality of Our Lady and other organized and informal religious societies. What is more, the Jesuits working in Płock were involved in propagating the Catholic faith. The author also discusses the importance of the school theatre in introducing the models of raising children promoted by Jesuits.
\end{abstract}

Key words: Płock in the $17^{\text {th }}$ and $18^{\text {th }}$ centuries, Jesuits

Na początku XVII w. Płock przeżywał ostatnie chwile swego „złotego wieku”. Stella Maria Szacherska, podsumowując bardzo korzystny dla miasta okres jego rozkwitu po przejściu pod panowanie Korony w drugiej dekadzie XVI w., przytoczyła opis Wawrzyńca z Wszerzecza, który przekazując potomnym obraz Płocka z 1603 r., widział go jeszcze kwitnącym: Miasto otoczone sadami, opasane dawnymi murami, po pożarze z $1545 \mathrm{r}$. odbudowane $w$ okresie pelnego dobrobytu świetniej niż uprzednio, obejmowało budynki wzniesione badź z cegiet, badź z drzewa, rynek, ulice, bramy, dojścia i drogi brukowane kamieniami, 14 bogatych kościołów i kaplic [...]. Do Płocka przybywali jeszcze kupcy 2002 .

1 Szerzej na ten temat w książce: W. Graczyk, J. Kwiatkowski, Jezuici w Płocku (1611-1773), Warszawa 
gdańscy, choć głównie dla skontaktowania się ze swymi szlacheckimi dostawcami. Miasto ożywiat handel tranzytowy ustawicznym ruchem todzi rybackich, matych statków, ptywaczek $i$ innych typów łodzi przewozowych ${ }^{2}$.

Ten okres rozkwitu skończył się w połowie XVII w., kiedy miasto wraz z całą Rzeczypospolitą wkroczyło w epokę stagnacji i upadku, spowodowaną wojną szwedzką. Pożary, epidemie i nadzwyczaj uciążliwe dla mieszkańców przemarsze oraz kwaterunki wojsk pustoszyły miasto.

W takich okolicznościach u progu kryzysu społeczno-gospodarczego, już od drugiej połowy XVI w. zaczęto podejmować próby sprowadzenia do Płocka jezuitów. Pierwszym, któremu zależało na tym był biskup Andrzej Noskowski (1545-1567). Za pośrednictwem nuncjusza Commendone w 1565 r., skierował prośbę do Franciszka Borgiasza, pełniącego po śmierci Layneza obowiązki wikariusza generalnego Towarzystwa, w sprawie przybycia jezuitów do diecezji płockiej i założenia kolegium. Przychylając się do prośby biskupa, Borgiasz wskazał jednocześnie na Płock jako na przyszłe miejsce pracy Towarzystwa. Ostateczną decyzję w sprawie lokalizacji ewentualnej placówki jezuickiej w diecezji płockiej mieli jednak podjąć dwaj specjalni wysłannicy: Franciszek Sunyer i Stanisław Rozdrażewski. Sunyer, który przybył do Płocka w grudniu 1565 r., uległ urokowi miasta, w liście do generała z 2 stycznia 1566 r. wyliczał wiele cech stolicy Mazowsza, które predysponowały ją na siedzibę jezuickiego kolegium. Płock widziany oczyma Sunyera miał położenie najpiękniejsze w całej Polsce i wielkiej części Europy; stolica biskupia, wielu duchownych, dla których można będzie wykładać teologię moralna, możliwość założenia konwiktu dla ubogiej młodzieży. Szlachta chętnie pośle dzieci do szkół w Płocku, ponieważ jest tu zdrowe powietrze. Ponadto Płock jest miastem królewskim i łatwiej będzie poskromić wybryki młodzieży niż w mieście biskupim. W Płocku wreszcie maja wysoka opinię o Towarzystwie $i$ wielkie z nim tacza nadzieje $e^{3}$.

Z kolei biskup Noskowski i kanonicy kapituły kolegiackiej w Pułtusku próbowali przekonać jezuickiego wysłannika, wskazując na zalety Pułtuska, który jak na mazowieckie warunki był dużym, bo liczącym ok. 600 domów miastem. Utrzymanie było w nim tanie, a majątki biskupa i kanoników, które miały stanowić zaplecze materialne kolegium, leżały w pobliżu miasta. Jezuita trwał jednak zdecydowanie przy idei lokalizacji kolegium w Płocku, stwierdził wręcz, że większa chwałę Boża widzi w Płocku, więc albo kolegium powstanie w Płocku, albo jezuici zrezygnuja z fundacji, bo nie grozi im bezrobocie, gdyż wielu ubiega się o ich sprowadzenie ${ }^{4}$.

Wobec tak kategorycznie postawionej sprawy lokalizacji kolegium, biskupowi Noskowskiemu nie pozostawało nic innego jak postaranie się o znalezienie odpowiedniej dla kolegium lokalizacji w stolicy diecezji. Nie było to zadanie łatwe. Na początek biskup zdecydował się przyjąć jezuitów do swojego pałacu, licząc, że dość szybko uda mu

2 S. M. Szacherska, Ztoty wiek miasta. Lata 1495-1580, w: Dzieje Ptocka, red. J. Chojnacki, A. Gieysztor, Płock 1973, s. 153.

${ }^{3}$ B. Natoński, Początki i rozwój Towarzystwa Jezusowego w Polsce, w: J. Brodrick, Powstanie i rozwój Towarzystwa Jezusowego, t. 1, Kraków 1969, s. 437-438.

${ }^{4}$ Ibidem, s. 438. 
się pozyskać na ten cel klasztor dominikanów. Otwarcie szkoły miało nastąpić 9 maja 1566 r. w pałacu biskupim w Płocku podczas zgromadzenia kapituły. Według planów Sunyera tego dnia powinna rozpocząć się już nauka w pięcioklasowej szkole z retoryką. Uczniowie mieli rekrutować się spośród synów szlachty mazowieckiej, którym szkoła w Płocku zaoszczędzała długich i kosztownych wypraw po wiedzę do Krakowa czy Wiednia.

Niestety, plany te nie doczekały się realizacji. Na przeszkodzie do utworzenia kolegium w Płocku stanęło wiele nieprzewidzianych trudności. Starania o klasztor dominikanów nie rokowały nadziei na pomyślne zakończenie. Na propozycję umiejscowienia jezuickiego kolegium przy Kolegiacie św. Michała i uposażenie go majątkiem kapituły tejże Kolegiaty nie zgodzili się kanonicy, mimo że w ramach rekompensaty za 5 utraconych wiosek mieli uzyskać jako swoje uposażenie cały dekanat. Chociaż biskup Noskowski zgromadził środki finansowe i materiały konieczne do budowy kolegium w Płocku, nie znalazło się jednak miejsce dla szkoły i kościoła. W tej sytuacji odpowiedzialny za całą misję Sunyer poprosił generała Borgiasza o zgodę na przyjęcie pierwotnie proponowanej fundacji pułtuskiej, w obawie, aby biskup, który wykazał już maksimum dobrej woli i zaangażował w sprawę kolegium duże środki finansowe, zniechęcony trudnościami nie zrezygnował z jezuickiego domu w swojej diecezji. Noskowski nie był jednak człowiekiem, który szybko ulegał zniechęceniu. Decyzję jezuitów o przejęciu szkoły w Pułtusku powitał z radością, obiecując równocześnie Sunyerowi, że będzie kontynuował starania o fundację kolegium także w Płocku, na którym tak jezuitom zależało ${ }^{5}$.

Chociaż nie zrealizowały się plany osadzenia w latach 60. XVI w. jezuitów w Płocku, to jednak zamiar biskupa Andrzeja Noskowskiego znalazł kontynuatora w osobie kolejnego jego następcy - biskupa Marcina Szyszkowskiego (1607-1616). Biskup Marcin Szyszkowski herbu Ostoja był znany jako jeden z najgorliwszych w XVII w. protektorów Towarzystwa Jezusowego. Franciszek Rzepnicki określił go nawet najzagorzalszym obrońca Towa$r z y s t w a^{6}$. Dobre relacje Szyszkowskiego z jezuitami sięgały jeszcze okresu, kiedy ten studiował w rzymskim kolegium Towarzystwa między innymi pod kierunkiem Roberta Bellarmina. Będąc od 1604 r. biskupem łuckim, utworzył jezuicką placówkę przy swojej katedrze, zaś w 1606 r. ufundował w Łucku kolegium ze szkołami i kursem teologii. Kiedy przeszedł w 1607 r. na stolicę biskupią w Płocku, czynił usilne starania około osadzenia jezuitów w stolicy diecezji. Sporządzona w 1773 r. Lustracja dóbr Kolegium Płockiego wzmiankuje o dokumencie wystawionym przez biskupa Szyszkowskiego już w 1610 r. i o tym, że Biskup niektóre place do erekcji Kolegium Płockiego opłacit i inne uczynit fundusze [...], tudzież ogród za Brama Grodzka na przeciwko kościoła św. Katarzyny, także folwark za Brama Dobrzyńska z ogrodami tam będacymi [fundował] ${ }^{7}$ Oficjalną prośbę

\footnotetext{
5 Ibidem, s. 439-440.

${ }^{6}$ Societatis Jesu erat defensor acerrimus. F. Rzepnicki, Vitae praesulum Poloniae, Magni Ducatus Lithuaniae res praecipue illorum temporibus gestae ad annum MDCCLX, t. 1, Posnaniae 1761, s. 346-347.

${ }^{7}$ Lustracja dóbr, wsiów, dziesięcin, summ i wszystkich in genere quocumque titulo funduszów przedtym do Kolegium Płockiego XX Jezuitów a teraz do Rzeczypospolitej należących. Biblioteka Polskiej Akademii Nauk w Krakowie, rkps 1156.
} 
do prowincjała litewskiego Pawła Bokszy, biskup Szyszkowski wystosował dopiero w roku następnym. Siedzibą szkoły miała być kamienica w pobliżu Kolegiaty św. Michała. Informatio de fundatione, fundatore et benefactores Collegii Plocensis Societatis Jesu podaje, że biskup przeznaczył za zgodą kapituły katedralnej na utrzymanie jezuickiej fundacji wieś Lutobork wraz z dziesięcinami ${ }^{8}$. Wkrótce przed awansem Szyszkowskiego na stolicę biskupią w Krakowie, fundacja jezuitów w Płocku zyskała w 1616 r. zatwierdzenie sejmu Rzeczypospolitej ${ }^{9}$. Dość szybko okazało się, że założenie szkoły w Płocku było niezwykle potrzebne, a obecność jezuitów spotkała się z bardzo przychylnym przyjęciem ze strony mazowieckiej szlachty ${ }^{10}$.

Zasadniczym celem wychowawczym, jaki stawiali sobie jezuiccy pedagodzy, było doprowadzenie człowieka do jego celu ostatecznego - zbawienia przez życie moralne zgodne z sumieniem i wiarą. Jezuita miał kształtować w wychowankach takie cnoty, jak: pobożność, posłuszeństwo, pilność, skromność i poprawność zachowania. Pomocą dla wychowawców i ich podopiecznych były liczne opracowania, które starały się podać wzór idealnego wychowanka oraz drogę do osiągnięcia ideału ${ }^{11}$. Aby pobudzić rozwój życia religijnego, w Kolegium kładziono duży nacisk na wypełnianie praktyk religijnych. Odmawiano wspólnie modlitwy poranne i wieczorne, zaś w soboty i dni poprzedzające święta kościelne uczniowie po zakończeniu lekcji śpiewali litanię do Matki Bożej lub litanię do Wszystkich Świętych. Dla urozmaicenia obowiązkowego uczestnictwa w codziennej mszy św. wprowadzono wspólny śpiew, a modlitewniki przeznaczone dla wychowanków zawierały bogate komentarze wyjaśniające liturgię. Dbano o regularne korzystanie z sakramentu pojednania, organizując comiesięczną spowiedź dla całej szkoły. Początkowa zachęta do częstej spowiedzi stopniowo stała się obowiązkową praktyką, kontrolowaną za pomocą systemu kartek wręczanych spowiednikowi. W uroczystości i święta uczniowie uczestniczyli w nieszporach, procesjach i uroczystych sumach ${ }^{12}$. Praktyki zewnętrzne miały pogłębić życie wewnętrzne i zmobilizować wychowanków do pracy nad sobą. Temu celowi służyły również uczniowskie bractwa i stowarzyszenia religijne, z których najliczniejszym i najbardziej znaczącym była Sodalicja Mariańska.

${ }^{8}$ [Episcopus] assignavit villam Lutoborae, a mensa Episcopalis, decimasque eisdem villae de Capitaneatus Lomzensis, cum consensu Venerabilis Capituli Plocensi. ARSI, Informatio de fundatione, fundatore et benefactores Collegii Plocensis Societatis Jesu, Historiae Fundationes Lithuanicae, ARSI, Pol. 75.

${ }^{9}$ Iż Wielebny Marcin Szyszkowski, Biskup Płocki, fundowat Ojców Jezuitów w mieście naszem Płocku, kamienice, domy i place im zakupil, za prośba tedy postów województwa płockiego i za zgoda wszech stanów Koronnych, kamienice te, domy i place, wolne od podatków wszelakich i ciężarów miejskich, wiecznymi czasy wolnymi czynimy atque immunitatibus et libertatibus Ecclesiasticis perpetuo adscribimus, authoritate praesentis Conventus. Volumina Legum. Przedruk Zbioru Praw staraniem xx. Pijarów w Warszawie od roku 1732 do roku 1782, Petersburg 1859, nr 106, s. 147.

${ }_{10}$ Plerique filios addiscebant, existimantes Nostros eorundem institutionem statim inchoavimus. Historia Residentiae Plocensis ab Anno 1611 ad Annum 1617, ARSI Lith. 38, f. 152a.

11 Szeroko rozpowszechnione były różnego rodzaju vademecum jezuickiego ucznia. S. Bednarski podzielił je na trzy grupy: podręczniki doskonałości, książki omawiające szczegółowo regulamin dnia i zbiory przykładów dla młodzieży. Książki te, podając zasady i wskazania praktyczne przekazywane wychowankom kolegiów, doskonale oddają ducha jezuickiego wychowania. Zob. S. Bednarski, Upadek i odrodzenie szkolnictwa jezuickiego w Polsce. Studium z dziejów kultury i szkolnictwa polskiego, Kraków 1933, s. 383.

${ }^{12}$ Ibidem, s. 385. 
Sodalicja - zdaniem S. Załęskiego - nie była zwyczajnym bractwem kościelnym, ale instytucja religijna i społeczna zarazem, zorganizowana madrze, ze swym statutem, samorzadem i jasno określonymi powinnościami. Uczczenie Matki Bożej, obrona honoru Maryi, przywileju Niepokalanego Jej poczęcia, udoskonalenie moralne własne i rozciagnięcie jego na jak najszersze koła, oto ich [członków Sodalicji] cel i zadanie ${ }^{13}$. Sodalicja była również ważną formą pobudzania aktywności społecznej i apostolskiej. Sodalisi uczyli się samorządności i racjonalnego gospodarowania wspólnym funduszem, pomagali mniej zdolnym kolegom w nauce oraz opiekowali się ubogimi i chorymi w szpitalach i przytułkach ${ }^{14}$. Członkami Sodalicji byli uczniowie wyróżniający się pobożnością i dobrymi wynikami w nauce. Do zarządu wchodzili prefekt Sodalicji, dwóch asystentów, czterech doradców, sekretarz i skarbnik. Cały zarząd był wybierany na zebraniu wszystkich członków. Nad sodalisami czuwał jeden z ojców wyznaczony jako moderator kongregacji $i^{15}$.

W sprawozdaniach z Kolegium płockiego znajduje się nieco wzmianek poświęconych działalności Sodalicji. Wiadomo, że powstała wkrótce po przybyciu jezuitów do Płocka. Po raz pierwszy o funkcji opiekuna Sodalicji dowiadujemy się z Katalogów domu płockiego z 1620 r. Był nim wówczas o. Jakub Orandowicz, prefekt szkół i profesor teologii moralnej ${ }^{16}$. Ponad 40 lat później, w 1667 r. kronikarz Kolegium, pisząc o rozwoju szkoły, zanotował również postęp uczniowskiej Kongregacji ${ }^{17}$. Szczególny wpływ na płocką Sodalicję wywarł przychylny jezuitom spowiednik norbertanek, ks. Stanisław Mikulski. Według przekazu z 1679 r., ks. Mikulski przed ołtarzem Matki Bożej Mazowieckiej dokonał uroczystego aktu oddania Sodalicji Kolegium płockiego pod opiekę Bogurodzicy $^{18}$. Być może właśnie wówczas nowi członkowie Kongregacji, jak nakazywał powszechnie przyjęty zwyczaj, otrzymali dyplomy podpisane przez moderatora, prefekta i sekretarza i srebrny medalik Matki Bożej, który mieli nosić jako order Maryi ${ }^{19}$. W tym samym roku kronikarz Kolegium zanotował, że Sodalicja poświęcona Dziewicy Anielskiej tak gorliwie ćwiczyła, że koniecznym stało się przeznaczenie oratorium dla drugiej gałęzi pobożności ${ }^{20}$. Nie jest wykluczone, że ten wzrost stowarzyszenia stał się

13 S. Załęski, Jezuici w Polsce, t. 1, Lwów 1900, s. 125.

${ }^{14}$ Encyklopedia wiedzy o jezuitach na ziemiach Polski i Litwy 1564-1995, oprac. L. Grzebień, Kraków 1996, s. 629.

15 S. Załęski, op. cit., s. 125-126.

${ }^{16}$ O. Jakub Orandowicz $\operatorname{Pr}$ [efectus] Congreg[ationis]B[eatae] V[irginae]. Catalogus personarum 1620, ARSI Lith. 6.

17 Szkoly kwitna publicznymi akademiami i innymi ćwiczeniami, zwłaszcza zaznaczyl się postęp w świętej Kongregacji. Annuae litterae 1667, ARSI Lith. 41, f. 38v.

${ }_{18}$ Auxit non modicum fervorem Sodalitii illustri exemplo et constanti pietate R. P. Stanislaus Mikulski e Divi Norberti familia confessarius Parthenonis eodem instituto viventis, ordini nostro perquam addictus. Diutiurnis ille precibus efflagitabit in Album Deiparae seniorum referri, et tandem voti compos factus publicamin coetu Sodalium Professionem fidei edidit, ac Magnae Matri, servitii perpetui sacramentum dixit. Annuae litterae 1679, ARSI Lith. 42, f. 75v.

\footnotetext{
19 S. Załęski, op. cit., s. 126.

${ }^{20}$ Annuae littearae 1679, ARSI Lith. 42, f. 75v.
} 
przyczyną podziału na tzw. Sodalicję Mniejszą, zrzeszającą uczniów klas gramatyki i Sodalicję Średnią, obejmującą młodzież z klas poetyki i retoryki ${ }^{21}$.

Oprócz Sodalicji Mariańskiej w Kolegium płockim istniały inne zorganizowane lub nieformalne bractwa pobożnościowe. I tak np. w 1648 r. kronikarz Kolegium odnotował wzrost kultu św. Stanisława Kostki ${ }^{22}$, czy św. Franciszka Ksawerego. Po ogłoszeniu przez nauczycieli dekady Świętego Apostoła Indii, uczniowie zostali rozpaleni nabożeństwem; bardzo wielu przyniosło podwójny a wielu poczwórny owoc pobożności $i^{23}$.

Bogate i dobrze zorganizowane życie religijne Kolegium płockiego owocowało licznymi powołaniami do stanu duchownego. Jezuiccy kronikarze skrupulatnie odnotowywali każdą pozytywną odpowiedź swych wychowanków na wezwanie do służby Bogu i ludziom. Absolwenci Kolegium trafiali nie tylko do Towarzystwa Jezusowego. Wielu wybierało zakon dominikanów, inni szli drogą św. Franciszka lub św. Benedykta, wzmacniali szeregi Kanoników Regularnych, Misjonarzy lub duchowieństwa diecezjalnego. Oto przykłady zapisów o powołaniach do stanu duchownego:

- [1667] Do naszego Towarzystwa wstapiło $w$ tym roku pięciu wybranych młodzieńców, pozostali skłaniają się do innych klasztorów ${ }^{24}$

- [1676] Dwaj uczniowie z naszych szkół zostali przyjęci do Towarzystwa. Do rodziny dominikanów jeden ${ }^{25}$;

- [1677] Z uczacych się do życia zakonnego wstapiło dziewięciu: do Towarzystwa dołaczyło trzech, do księży diecezjalnych jeden, do zakonu dominikanów dwóch, do benedyktynów dwóch $i$ do kanoników regularnych jeden ${ }^{26}$;

- [1679] Dwóch z naszych uczniów zostało pociagniętych za naszym przykładem pod sztandar Chrystusa, trzech wstapito do Towarzystwa ${ }^{27}$;

- [1702] Ćwiczenia duchowe przyniosty niemaly owoc, kiedy młodzieńcy odznaczajacy się cnota uzyskana $w$ szkołach, aby bardziej się udoskonalić przywdziali habity: jeden św. Franciszka inny św. Dominika, trzech benedyktynów, jeden wstapit do klasztoru misjonarzy, wszyscy cieszac się ze swego stanu ${ }^{28}$.

Działalność religijna Kolegium nie pozostawała bez znaczenia dla duszpasterstwa w mieście. Pracujący w Płocku jezuici włączali się aktywnie w prace duszpasterskie. Wśród pełnionych przez nich funkcji, Katalogi zawsze wymieniają urząd kaznodziei i spowiednika. Właśnie głoszeniu Słowa Bożego oddawał się w czasie swego pobytu w Płocku św. Andrzej Bobola ${ }^{29}$.

\footnotetext{
${ }^{21}$ Encyklopedia wiedzy o jezuitach..., s. 629.

${ }^{22}$ Wielu chorych uczniów wzywających pomocy Błogosławionego, otrzymało zdrowie. Annuae litterae 1648, ARSI Lith. 39, f. 233-233v.

${ }_{23}$ Annuae litterae 1684, ARSI Lith. 42, f. 136v; Owocem pobożności, o którym mowa, były zapewne dobrowolne wyrzeczenia, akty pobożności i uczynki miłosierdzia.

24 Annuae litterae 1667, ARSI Lith 41, f. 38v.

${ }_{25}$ Annuae litterae 1676, ARSI Lith. 41, f. 385.

${ }^{26}$ Annuae litterae 1677, ARSI Lith. 41, f. 385v.

27 Annuae litterae 1679, ARSI Lith. 42, f. 75v.

28 Annuae litterae 1702, ARSI Lith. 44, f. 262.

${ }^{29}$ Catalogus personarum 1634, ARSI Lith. 6, f. 302b.
} 
O tej formie aktywności świadczy wiele kronikarskich zapisów. Niektóre z nich są bardzo wymowne. Tak np. w 1685 r. jezuicki kronikarz zanotował: Przez Stolice Apostolska został ogłoszony nadzwyczajny Rok Jubileuszowy, jako dziękczynienie Bożej sprawiedliwości za ocalenie od Turków. Aby z dobrodziejstw tego roku lud chrześcijański mieszkajacy w Płocku jak najobficiej skorzystał, ojcowie Towarzystwa Jezusowego włączyli sie $w$ postuge sakramentalna, zwłaszcza przez zasiadanie $w$ Trybunale Uzdrowienia. $Z$ ich zbawiennej postugi korzystała wielka liczba mieszczan a takíe mieszkańcy okolicznych $w s i^{30}$.

Jezuici angażowali się w duszpasterstwo zwyczajne nie tylko przy okazji świąt czy lat jubileuszowych. Posługa sakramentalna, zwłaszcza zasiadanie $w$ Trybunale Uzdrowienia, przygotowanie do pierwszej Komunii św. czy też duszpasterstwo chorych i więźniów stanowiło część codziennych zadań mieszkańców płockiego domu Towarzystwa Jezusowego. Z zestawień za lata 1754-1757 wynika, że w ciągu tylko tych trzech lat płoccy jezuici wysłuchali 42779 spowiedzi, 121 dzieciom udzielili pierwszej Komunii św., 39 osób przygotowali na śmierć. Ponadto pełnili posługę sakramentalną wśród 133 chorych i uwięzionych, wygłosili 21 egzort oraz przeprowadzili 4 misje i rekolekcje. Prace duszpasterskie zaowocowały przejściem na katolicyzm 3 wyznawców judaizmu i 3 członków Kościoła prawosławnego ${ }^{31}$.

Aktywność duszpasterska była wyrazem ścisłej współpracy wspólnoty Kolegium ze społecznością miasta. Jezuici przywiązywali wielką wagę do ukształtowania w swoich wychowankach wrażliwości na potrzeby ludzi oczekujących wsparcia. Wymownym przykładem takiej działalności była pomoc w czasie często nawiedzających Płock epidemii. Wielu jezuitów pracujących w Kolegium przypieczętowało tę służbę ofiarą życia. Służąc pomocą choćby w czasie epidemii w 1656 r. zmarli następujący zakonnicy - ks. Wojciech Kaczyński i ks. Wojciech Popławski, zaś w 1708 r. - br. Wawrzyniec Gniewkowski, br. Urban Markowski - infirmarz, ks. Adam Lipowski - profesor teologii moralnej i ks. Kazimierz Szczytt - kaznodzieja, prefekt szkół i biblioteki ${ }^{32}$.

W kolegiach jezuickich przywiązywano także dużą wagę do formacji patriotycznej. Ludwik Piechnik, analizując przemiany w szkolnictwie jezuickim w XVIII w., zauważył, że szkoła jezuicka nawet $w$ okresie upadku [...] wychowywała młodzież $w$ patriotyzmie. Kroniki kolegiów petne sa opisów zachowania się uczniów w czasie wojen. Uczestniczyli oni w specjalnych nabożeństwach majacych na celu wyproszenie u Boga zwycięstwa oręża polskiego, podejmowali najcięższe umartwienia (m.in. biczowanie). Ilość studentów filozofii malała, ponieważ starsi uczniowie spieszyli do wojska. Oprócz kronik pozostały z tego okresu listy prowincjałów wzywające szkoły, nauczycieli i uczniów do modlitw $w$ intencji ojczyzny ${ }^{33}$.

\footnotetext{
30 Annuae litterae 1685, ARSI Lith. 42, f. $268-268 \mathrm{v}$.

31 Dane opracowane na podstawie tabel zawartych w pracy J. Flagi Działalność duszpasterska zakonów w drugiej połowie XVIII w. 1767-1772, Lublin 1986.

32 Encyklopedia wiedzy o jezuitach..., s. 148.

${ }^{33}$ L. Piechnik, Przemiany w szkolnictwie jezuickim w Polsce XVIII wieku, „Roczniki humanistyczne” 25, 1977, z. 2, s. 53.
} 
Specyficzną dla kolegiów jezuickich formą wychowania patriotycznego i formacji religijnej był teatr szkolny ${ }^{34}$. Zdaniem I. Kadulskiej gorliwość teatralna jezuitów wynikata najczęściej z oczekiwań widzów, z rezonansu społecznego przedstawień, które do potowy XVIII wieku byly nieodtacznym atrybutem każdej ważniejszej uroczystości. Wśród uświetnianych okazji były zarówno rocznice zwycięstw, uroczystości domu panującego, powitania króla, dostojników Kościola, wysokich urzędników, jak i ingresy biskupa i senatorskie. Łaczono występy z wydarzeniami takimi, jak zjazdy szlachty na sesje trybunalskie, na sejmiki $i$ sady. Czczono także święta prywatne - rodzinne, koalicje wielkich rodów, śluby, prymicje, urodziny, imieniny, uroczyste pogrzeby ${ }^{35}$. Dla wychowania patriotycznego największe znaczenie miały dramaty historyczne i sztuki obyczajowe, w których przedstawiano i chwalono cnoty obywatelskie, a wyśmiewano narodowe wady, głupotę i przewrotność ludzką.

W Płocku jezuici rozwijali tę formę edukacji od początku istnienia ich domu. Już w 1612 r. uczniowie z jezuickiej szkoły wystawili Dialog, który wzbudził zdumienie i zachwyt słuchaczy. Wielu twierdziło nawet, że nigdy nie widzieli czegoś podobnego ${ }^{36}$. W 1614 r. został wystawiony Dialog z okazji uroczystości Bożego Ciała ${ }^{37}$. Wyjątkowo bogaty w wydarzenia teatralne okazał się rok 1616. Dialogi wystawiono wówczas czterokrotnie ${ }^{38}$. Kroniki Kolegium płockiego odnotowały w XVII w. kilkanaście publicznych występów teatralnych. Były to bliżej nieokreślone występy publiczne w latach 1666-1667; gratulacje na rynku oraz dialogi i panegiryki w kościele na ingres biskupa płockiego Bonawentury Madalińskiego z 27 I 1674 r.; deklamacje i występy publiczne z 1685 r.; dramat zapustny na dziedzińcu szkół z 27 II 1686; dramat na zakończenie roku szkolnego z 31 VII 1686 r.; dramat na uroczystość św. Ignacego Loyoli z 31 VII 1687 r.; dramat w dzień św. Stanisława Kostki z 13 XI 1687 r. oraz akt publiczny na ingres biskupa płockiego Jędrzeja Chryzostoma Załuskiego ${ }^{39}$. Ostatnim występem teatralnym w XVII w. była wystawiona w $1678 \mathrm{r}$. sztuka Fortuna Palladi foederata - alegoryczna analiza sytuacji I Rzeczypospolitej ${ }^{40}$.

34 Stabilność sceny jezuickiej, jej zakotwiczenie w systemie edukacyjnym kolegiów, a przez to jej powszechność, dawaty temu teatrowi możliwość (do tej pory niespotykana) wplywania na publiczność i kształtowania jej postaw, oddziaływania propagandowego $w$ najrozmaitszych płaszczyznach - dydaktycznej, wyznaniowej $i$ politycznej. K. Kotońska, Uwagi o stylu polskiej tragedii jezuickiej XVI i początku XVII wieku, w: L. Grzebień, S. Obirek (red.), Jezuici a kultura polska. Materiały sympozjum z okazji Jubileuszu 500-lecia urodzin Ignacego Loyoli (1491-1991) i 450-lecia powstania Towarzystwa Jezusowego (1540-1990), dz. cyt., s. 143.

35 I. Kadulska, Dlugie trwanie baroku w polskim teatrze jezuickim XVIII wieku, w: Jezuicka ars educandi. Prace ofiarowane Księdzu Profesorowi Ludwikowi Piechnikowi SJ, Kraków 1995, s. 129.

${ }^{36}$ Auxit solemnitatem altero vis exhibitus Dialogus a pueris Scholae Ecclesiae nostrae, qui ita rem exprimente actionem recrearunt et ad pietatem excitarunt, ut plerique se nihil simile vidisse affirmarent. ARSI Lith. 38, f. $152 \mathrm{a}-152$ av.

37 Pro festo etiam Corporis Christi Dialogus exhibitus solemnitatem promovit. ARSI Lith. 38, f. 152 bv.

${ }^{38}$ Dialogi etiam quater facti admirationem plebis et nobilium in tradenda nostrae institutioni sua iuventuti erga nos affectum conciliarunt. ARSI Lith. 38, f. 152c-152cv.

${ }^{39}$ Zestawienie na podstawie pracy J. Okonia Dramat i teatr szkolny. Sceny jezuickie XVII wieku, WrocławWarszawa-Kraków 1970.

40 Sztuka opowiada o losach cesarza chińskiego Xunchiusza, który najwyższe urzędy w państwie zaczął powierzać tylko ludziom odpowiednio przygotowanym i wykształconym. Takie postępowanie wywołało niezadowolenie wśród mandarynów, lubiących swawolę i rozrzutność. Jeden z dostojników, Lama, staje na czele 
W XVIII w., po zakończeniu wojen, Kolegium płockie wznowiło aktywność teatralną ${ }^{41}$. Oprócz panegiryków na cześć biskupów płockich i mazowieckich dostojników w repertuarze znalazła się wystawiona w 1720 r. sztuka o trzech japońskich jezuitach, męczennikach oraz dramat historyczny, którego bohaterem był książę mazowiecki Ziemowit ${ }^{42}$.

Autorami sztuk byli zwykle profesorowie Kolegium, chociaż przygotowujący przedstawienia często korzystali z opublikowanego drukiem dorobku współbraci z innych szkół. Zachowały się informacje o twórczości dramatopisarskiej Łukasza Paprockiego, rektora płockiego Kolegium w latach $1653-1657^{43}$, zaś o autorze sztuk, nauczycielu retoryki w latach 1660-1661, Tomaszu Seligmacherze pozostała w Płocku opinia człowieka niezwykle uzdolnionego ${ }^{44}$. Warto dodać, że wspomniany dramat o księciu Ziemowicie w 1720 r. napisał wykładający retorykę, Ignacy Wilkinowicz ${ }^{45}$.

Przedstawienia teatralne wymagały odpowiedniego zaplecza. Przykładowo do wystawienia Fortuna Palladi foederata koniecznym było zbudowanie sceny umożliwiającej sukcesywną zmianę pięciu odmian dekoracji ${ }^{46}$. W zapisach z 1697 r. znajduje się informacja, że Stefan Laskowski, ówczesny rektor, dla uzyskania bardziej obszernej sceny wzniósł jednopiętrowy budynek, w którym na pierwszym piętrze znalazła się jasno oświetlona sala przeznaczona do występów teatralnych ${ }^{47}$. Zniszczenia z początku XVIII w. uniemożliwiły dalsze inwestycje i rozbudowę płockiej sceny. Pozostała jednak świadomość wielkiego znaczenia inscenizacji, tym bardziej, że teatr jezuicki, pozostający często między swojskościa a cudzoziemszczyzną ${ }^{48}$, stał się cennym narzędziem budzenia pobożności i kształtowania postawy patriotyzmu.

buntu mandarynów, zakończonego uwięzieniem mądrego cesarza. Zob. J. Okoń, Dramat i teatr szkolny. Sceny jezuickie XVII wieku, s. 124-125.

${ }^{41}$ Płockie panegiryki często były wydawane drukiem. Z XVIII w. pochodzi opublikowana w Warszawie w 1737 r. Corona Patriae a Primo ex Polona Patria Nobilitate coronarii nominis Plocensi Antistitae, sexagesimus Praesul, patrium suum montem coronans Infulis, Antonius Sebastianus a Dembowa- góra Dembowski, Eppus Plocensis LXVII. Zob. J. Brown, Biblioteka pisarzów Asystencji Polskiej Towarzystwa Jezusowego, Poznań 1862, s. 50.

${ }^{42}$ Magnus Congregatorum Joannis Petri et Andreae Ad Martyrii Lauream extensa. A Perillustri, Illustri ac Magnifica Collegii Karnkoviani Plocensis Societatis Jesu in tragicam scenam data anno 1720.[...] Veritas in fundo per Ziemovitum Plocensium ducem veneno potum, Infortunatum esse compotationum eventum agnoscere reperta. Antecinerali Dramate a Perillustri, Illustri ac Magnifica Iuventute Rhetorica Collegii Karnkoviani Plocensis Societatis Jesu promulgata Anno 1720, 10 Februarii. C. Sommervogel, Bibliotheque de la Compagne de Jesus, Bruxelles - Paris 1895, t. 6., kol. 900-901.

43 J. Okoń, Dramat i teatr szkolny. Sceny jezuickie XVII wieku, s. 413.

44 Ibidem, s. 414.

${ }^{45}$ C. Sommervogel, Bibliotheque de la Compagne de Jésus, t. 6., Bruxelles - Paris 1895, kol. 901.

46 J. Okoń, op. cit., s. 249.

47 Ibidem.

48 J. Okoń, Teatr jezuicki w Polsce: pomiędzy swojskością a cudzoziemszczyzna, w: Jezuici a kultura polska. Materiaty sympozjum z okazji Jubileuszu 500-lecia urodzin Ignacego Loyoli (1491-1991) i 450-lecia powstania Towarzystwa Jezusowego (1540-1990), red. L. Grzebień, S. Obirek, Kraków 1993, s. $227-241$. 
Reasumując, należy podkreślić, że Kolegium płockie z dużym powodzeniem starało się wypełnić w czasie lat swego istnienia postawione przed nim zadanie kształtowania umysłów i serc swoich wychowanków. Losy płockich jezuitów stanowią część historii miasta i lokalnej społeczności, w której przyszło im żyć i pracować. Jezuicka szkoła stanowiła jeden z najbardziej aktywnych ośrodków edukacyjnych miasta, w charakterze i stylu działalności zbliżonego do współczesnego duszpasterstwa akademickiego. 


\title{
Edukacja dziewcząt pod zaborem pruskim na przelomie XVIII i XIX wieku
}

\begin{abstract}
The education of girls under Prussian rule at the turn of the eighteenth and nineteenth centuries

At the turn of $18^{\text {th }}$ and $19^{\text {th }}$ century the education of women on Polish territory underwent a gradual enlargement. Already in the period of the reforms of the National Education Commission, more girls received education; after the seizure of Greater Poland (Wielkopolska) by Prussia in 1793, Germany implemented their educational system, that meant the acceleration of development. Compulsory schooling in Prussian was introduced in 1794, however, it was still poorly enforced. In Prussia girls often attended lower school due to the requirement for a Protestant to have the ability to read the Scriptures. More and more often, they also attended secondary schools with syllabuses not extensively devoted to Latin, but to more practical skills, connected with so-called woman's work, and to religious education. In Wielkopolska, lower education, private schools for girls and schooling by tutors in convents and midwifery schools increased significantly. Nevertheless, girls did not attend ordinary secondary schools, which retained an emphasis on teaching Latin, or colleges.
\end{abstract}

Keywords: the history of education, girls' education, Prussian

Zagadnienie historii edukacji dziewcząt nie było dotąd przedmiotem wystarczającej uwagi historiografii polskiej. Opracowania Witolda Molika, Izabelli Rusinowej, czy Moniki Abram nie wyczerpują tematu ani nawet nie dotyczą interesującego mnie okresu' ${ }^{1}$. Zupełnie inna jest sytuacja w historiografii niemieckiej, gdzie to ważne zagadnienie doczekało się wyczerpujących książkowych opracowań syntetycznych i analitycznych (zob. przypisy w tekście). W ten sposób moje opracowanie, korzystające zarówno z doświad-

1 W. Molik, Drogi edukacji córek ziemiańskich w Wielkopolsce XIX i pocz. XX w., w: Studia kobiece z psychologii, filozofii i historii, red. J. Miluskiej i E. Pakszys, Poznań 1995, s. 147-168; M. Abram, Problem wykształcenia kobiet $w$ publicystyce poznańskiej XIX w., ibidem, s. 169-178; I. Rusinowa, Ideały wychowawcze kobiet wśród ziemiaństwa polskiego w XVIII wieku, w: Kobiety i edukacja na ziemiach polskich w XIX i XX wieku, red. A. Żarnowska, A. Szwarc, Warszawa 1995, s. 63-69. 
czeń niemieckich, jak i źródeł archiwalnych i drukowanych wypełnia lukę w tym zakresie. Konieczne są jednak dalsze, obszerniejsze, monograficzne prace nad edukacją kobiet, chociaż dla XIX w. stan opracowania dziejów edukacji i szkolnictwa na ziemiach polskich jest wyrywkowy i bardzo słaby.

\section{System społeczny i szkoła}

System szkolny epoki nowożytnej przeznaczony był zasadniczo dla chłopców, a w Rzeczypospolitej XVIII w. poziom scholaryzacji na tle pruskim był bardzo niski. Prusy miały jeden z najlepszych systemów edukacyjnych w Europie, o czym u nas mówi się za mało. Pod koniec XVIII w. w monarchii Hohenzollernów do szkoły uczęszczało ok. 50\% dzieci², natomiast w departamencie poznańskim, jak wynika ze statystyki $1803 \mathrm{r}$. jedynie $12 \%$ dzieci w wieku szkolnym. Jest to naturalnie tylko pewne przybliżenie, ze względu na niedoskonałość ówczesnej statystyki³ ${ }^{3}$ Wielkopolska była tymczasem najlepiej rozwiniętą kulturalnie prowincją polską i idąc na wschód sytuacja ulegała pogorszeniu, podobnie jak sieć parafialna stawała się coraz rzadsza. Rozpatrując odrębnie edukację w miastach poznańskich, stwierdzimy, że odsetek dzieci uczęszczających do szkoły sięgał tam w 1803 r. nawet 30\% ${ }^{4}$. Stopień alfabetyzacji w Prusach już w 1816 r. był niezwykle wysoki i wynosił $60 \%$ dzieci w wieku szkolnym. Przy tym duże były różnice regionalne. Jeżeli w 1816 r. scholaryzacja w prowincji saskiej wynosiła 80\%, to w prowincji poznańskiej na skutek postępów po 1793 r. i w Księstwie Warszawskim i tak zaledwie $20 \%{ }^{5}$. Do XVIII w. tylko mężczyźni uczęszczali do szkół niższych, czyli parafialnych, w połowie tego stulecia pojawiły się tam dziewczęta. Całkowicie męskie były szkoły średnie - jezuickie i eksjezuickie, pijarów czy bazylianów, oraz Uniwersytet Krakowski. Musimy pamiętać, że szkoła ówczesna w bardzo ograniczonym stopniu miała też funkcję przysposobienia zawodowego. Miała raczej socjalizować szlachtę do życia

2 P. Lundgreen, Sozialgeschichte der deutschen Schule im Überblick, Teil I: 1770-1918, Göttingen 1980; por. W. Neugebauer, Absolutistischer Staat und Schulwirklichkeit in Brandenburg-Preussen, Berlin-New York 1985, s. 277.

${ }^{3}$ General Tabelle über die Beschaffenheit der Schulen in den 17. Landrathlichen Kreisen das Posenschen Cammer Departaments, 1803, AGAD (Archiwum Główne Akt Dawnych), GDPP (Generalne Dyrektorium Prusy Południowe), I 1612.

${ }^{4}$ Generalna tabela o stanie szkół w miastach 6 inspekcji radców podatkowych w poznańskim departamencie kamery, AGAD, GDPP, I 1612, n.p.

${ }^{5}$ F.-M. Kuhlemann, Modernisierung und Disciplinierung. Sozialgeschichte des preußischen Volksschulwesens 1794-1872, Göttingen 1992, s. 107-119; R. Engelsing, Die Perioden des Lesergeschichte in der Neuzeit, w: idem, Zur Sozialgeschichte deutscher Mittel- und Unterschichten, Göttingen 1978, s. 122-141; R. Schenda, Alphabetisierung und Literarisierungsprozesse in Westeuropa im 18. und 19. Jahrhundert, w: Sozialer und kultureller Wandel in der ländlichen Welt des 18 Jahrhunderts, hg. E. Hinrichs, G.Wiegelmann, Wolfenbüttel 1982, s. 1-19; G. Friedrich, Das niedere Schulwesen, Handbuch der deutschen Bildungsgeschichte, hg. K.-E. Jeismann, P. Lundgreen, München 1987, Bd. 3, s. 128; W. Neugebauer, Das Bildungswesen in Preußen seit der Mitte des 17. Jahrhunderts, w: Handbuch der Preussischen Geschichte, hg. O. Büsch, BerlinNew York 1992, Bd. 2, s. 715, 721, 725; H. U. Wehler, Deutsche Gesellschaftsgeschichte, München 1987, Bd. 2, s. 478-479, 485-486; Bd. 3, s. 400. 
obywatelskiego, publicznego i towarzyskiego w ogólności, pozwalać na poruszanie się poza światem domowym. Rdzeniem nauczania była łacina, będąca językiem sacrum, językiem prawa i językiem stanu szlacheckiego, i łacińska kultura, a więc literatura, mitologia, historia, filozofia, maksymy, aforyzmy, wiersze. Tworzyły one tkankę szlacheckiej kultury dnia codziennego, odróżniającej ten stan rządzący od chłopów i w dużym stopniu mieszczan. To odróżnienie lepszych od gorszych było niezbędne ze względu na hierar-

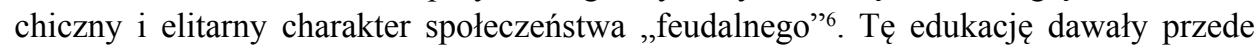
wszystkim szkoły średnie jezuickie i pijarskie, chociaż oczywiście inne elementy nauczania występowały również.

Z perspektywy funkcji ekonomicznej edukacji, podstawowe nauczanie klas niższych miało jednak pozaszkolny charakter i polegało na naśladowaniu przez dzieci rodziców w gospodarstwie chłopskim, czy mieszczańskim, czy naśladowanie mistrza cechowego, czy ojca szlachcica prowadzącego swój majątek ziemski, o ile sam to robił, co też nie było powszechne. Tak było w wypadku chłopców, jak i dziewcząt. Uniwersytet pełnił funkcję ograniczoną - do zawodu przygotowywał tylko część lekarzy (ale już nie np. chirurgów), prawników - chociaż znaczna część w Polsce miała przygotowanie jedynie praktyczne - teologów, nauczycieli. W Prusach po studiach prawniczych, kameralistycznych i nawet teologicznych oraz wojskowych tworzyła się też znacząca warstwa urzędnicza, wykształcone mieszczaństwo i głównie szlachecka kasta oficerska. Ważną rolę odgrywały więc szkoły kadetów, kształcące elitę oficerską, ale i tutaj większość kadry oficerskiej miała jedynie przygotowanie praktyczne w pułku, gdzie oddawana była w wieku 12-14 lat. Trzeba powiedzieć, że ambicje edukacyjne polskiej sarmackiej szlachty były ograniczone, prestiż wykształcenia niewielki, a książki nie cieszyły się w domach szlachty wielkim powodzeniem.

\section{Zmiany w myśleniu o edukacja kobiet w epoce Oświecenia w Prusach i praktyka}

Życie salonowe arystokracji epoki Oświecenia bardzo wspierało edukację kobiet z elit. Kobieta była tu właściwie równa mężczyźnie i brała partnerski udział w konwersacji, wpływając nawet znacznie na decyzje polityczne. Tematem rozmów była nauka, sztuka, literatura, polityka, ale też sprawy społeczne, nawet rolnictwo i rzemiosło. Sprawy praktyczne i przyziemnie były również modne. Wymagało to sporej erudycji i oczytania. Ta równość widoczna nie tylko we Francji i Prusach, ale też na dworze króla Stanisława Augusta Poniatowskiego, dotyczyła jednak tylko dam z elit, na których nie ciążyły obowiązki rodzicielskie i gospodarskie ${ }^{7}$.

\footnotetext{
${ }^{6}$ Pojęcie feudalizmu rozumiem, tak jak funkcjonuje od XVIII w., jako społeczno-politycznego systemu rządów szlacheckich opartych na zasadzie urodzenia, a nie zasług, na poddaństwie i pańszczyźnie chłopów.

${ }^{7}$ B. Craveri, Zloty wiek konwersacji, Warszawa 2009; D. Łukasiewicz, Francuskie wzory kulturowe w XVIII wieku i kryzys moralny Prus, w: idem, Zło to niechrześcijańskie i nieludzkie. Historia dzieciobójstwa i inne studia z dziejów codzienności, Poznań 2014, s. 145-176.
} 
Polska w całej Europie miała opinię kraju, gdzie wpływy kobiet były znaczne, co nie było w tym czasie jednak komplementem, bo uważano to wywrócenie naturalnego porządku rzeczy. Król pruski Fryderyk II powiedział na przykład w 1752 r., że kobiety u nas rządzą, a mężczyźni w tym czasie piją. Cesarz Francuzów miał powiedzieć w 1806 r. do swojego posła, którego wyprawiał do Polski: Jedziesz do kraju, gdzie mężczyźni nic nie znacza, gdzie kobiety sq wszystkim. Nawet wybitny przedwojenny historyk Władysław Konopczyński stworzył na tę okoliczność książkę, Kiedy nami rzadziły kobiety, gdzie stwierdza powszechne i namiętne zainteresowanie dam z wyższych sfer dla oddziaływania na politykę. Ostatnio tę aktywność potwierdza Richard Butterwick, a niegdyś w duchu konserwatywnego potępienia Walerian Kalinka w dziele Sejm Czteroletni. Wróćmy jednak do Napoleona - w 1806 r. podczas balu w Poznaniu cesarz przepytywał Wirydiannę Fiszerową na okoliczność zatrudnień jej męża. Co chciał tym sposobem osiągnąć? Wirydianna nie miała wątpliwości: wybrat tę osobliwa metodę indagacji na skutek doniesień, że kobiety polskie to intrygantki, które za nos wodza swoich mężów ${ }^{8}$. Ale przecież i Montesquieu nie był osamotniony w opinii, że Francją epoki Oświecenia we wszystkich szczegółach w ogóle rządziły kobiety, posługując się swoimi mężczyznami, poczynając od króla, który był pod absolutna władza kobiet, które tworzą jakby republikę i nawzajem się wspierają ${ }^{9}$.

Myśliciele epoki Oświecenia uznali, że dotychczasowa, głównie domowa lub zakonna, religijna edukacja dziewcząt jest dalece niewystarczająca i np. Campe pisał o konieczności zaangażowania się państwa w jej poszerzenie. Dowodził, że dziewczęta będą matkami wychowującymi synów i stąd stan ich wiedzy jest dla państwa sprawą zasadni$\mathrm{cząa}^{10}$. Kiedy mówi się o dążeniach emancypacyjnych kobiet epoki Oświecenia w Europie tego czasu, zwykle wspomina się najgłośniejsze wystąpienia Francuzki Olimpii de Gouges z czasów Wielkiej Rewolucji Francuskiej i Angielki Mary Wollstonecraft z 1792 r. Tymczasem pruski biurokrata i tajny radca, którego ojciec był wiejskim nauczycielem, w końcu prezydent Królewca Theodor Gottlieb Hippel (1741-1796) w 1792 r. opublikował rozprawę Über die bürgerliche Verbesserung der Weiber. Opowiadał się w niej za pełnymi prawami edukacyjnymi i politycznymi dla kobiet. Dawał świadectwo często postępowym poglądom pruskiego wykształconego mieszczaństwa. Hippel uważał, że

${ }^{8}$ R. Butterwick, Polska rewolucja a Kościól Katolicki 1788-1792, Kraków 2012, s. 294-296; W. Konopczyński, Kiedy nami rządzily kobiety, Londyn 1960; D. Rolnik, Portret szlachty czasów stanisławowskich epoki kryzysu, odrodzenia i upadku Rzeczypospolitej w pamiętnikach polskich, Katowice 2009, s. 172-174; W. Fiszerowa, Dzieje moje własne i osób postronnych, Londyn 1975; S. Salmonowicz, Fryderyka Wielkiego opinie o Polakach, w: Od Prus Książęcych do Królestwa Pruskiego, Olsztyn 1992, s. 129-136; W. Kalinka, Sejm Czteroletni, Warszawa 1991, t. 1, s. 202-204; M. Bogucka, Białogłowa $w$ dawnej Polsce. Kobieta w Polsce XVI-XVIII w. na tle porównawczym, Warszawa 1998, s. 208-220; J. Skowronek, Debiuty polityczne kobiet $w$ epoce rozbiorowej i początkach epoki porozbiorowej 1772-1831, w: Kobieta i świat polityki. Polska na tle porównawczym w XIX i początkach XX w., red. A. Żarnowska, A. Szwarc, Warszawa 1994, s. 29-44; J. Michalski, Gdyby nami rządzily kobiety (Poglądy Amelii Mniszchowej na reformę Rzeczypospolitej), w: Studia Historyczne z XVIII i XIX wieku, Warszawa 2007, t. 2, s. 97-108.

${ }^{9}$ Ch. de Montesquieu, Listy perskie, Madryt 2000, s. 173.

${ }^{10} \mathrm{Ch}$. Mayer, Die Anfänge einer Institutionlisierten Mädchenerziehung an der Wende von 18. zum 19. Jahrhundert, w: Geschichte der Mädchen- und Frauenbildung, hg. E. Kleinau, K. Opitz, Frankfurt/New York 1996, Bd. 1, s. 373-374. 
zmiana sposobu wychowania i edukacji kobiet oraz konwenansów spowoduje, iż kobiety staną się równe mężczyznom pod względem wykształcenia i odpowiedzialności. Edukacja chłopców i dziewcząt do okresu dojrzewania miała być koedukacyjna. Uważał wręcz, co już było dosyć niezwykłe, że kobiety powinny pracować jako uczeni, pastorzy, prawnicy, lekarze, urzędnicy czy politycy, co wymagało oczywiście pełnych praw edukacyjnych. Amalia Holst (1758-1829), córka wybitnego kameralisty Justiego, dobrze wykształcona, była guwernantką i razem z mężem założyła prywatną szkołę dla dziewcząt. W traktacie z 1802 r. pisała o zdolności kobiet, ale tylko z elit, do wyższych funkcji duchowych, przeciwstawiając się poglądowi, że nadają się one jedynie dla domu, dzieci i rodziny. Zwracała uwagę, że w kwestii „umowy społecznej”, męski argument o fizycznej słabości kobiet może mieć zastosowanie tylko do stanu natury, a nie cywilizacji, gdzie nie decyduje już brutalna przemoc silniejszego ${ }^{11}$.

Zazwyczaj jednak poglądy myślicieli epoki Oświecenia były zdecydowanie bardziej jednostronnie, widzące w kobiecie przede wszystkim matkę i żonę. W tym duchu wypowiadał się Jean Jacques Rousseau w Emilu (1762) i też Niemcy i Prusacy, jak Joachim Heinrich Campe (1746-1818), Johann Heinrich Pestalozzi, Friedrich Daniel Ernst Schleiermacher (1768-1834), czy Amalia Holst ${ }^{12}$. Rousseau uważał bardzo w duchu mieszczańskim, że wychowanie kobiety powinno być ukierunkowane przede wszystkim na podobanie się mężczyźnie, dlatego ma być ona przede wszystkim miła i sympatyczna, jednak relacja płci opierać się ma na miłości. Wprawdzie, jak sądził, kobieta winna się podporządkować mężczyźnie, jednak jej wdzięk, kokieteria i inne kobiece sposoby powodowały, że miała duże możliwości wpływania na swoją sytuację ${ }^{13}$. Filantropista Campe przyznawał w swoich radach dla córki z 1789 r. wielokrotnie wznawianych, że kobiety są podporządkowane władzy mężczyzn i nie jest to dla nich sytuacja korzystna. Przypominają - uważał - bluszcz, który może żyć, tylko wijąc się wokół dębu, pozbawiony oparcia ginie rozdeptany, czego bynajmniej nie pochwalał. Campe stwierdzał ,realistycznie", że w obecnej sytuacji najważniejszy interes kobiet, to wyjście za mąż. Nie oznacza to jednak, że ma być pozbawiona edukacji. Campe sądził wszakże, że chodzi przede wszystkim o uformowanie łagodnego kobiecego charakteru, dobroci serca, cnotliwości, pracowitości, zamiłowaniu porządku, dzięki którym zdobędzie większy wpływ na mężczyzn. Wiedza kobiety powinna się więc koncentrować przede wszystkim na domu i rodzinie ${ }^{14}$. Dla Pestalozziego (1746-1827) centralną figurą, jeżeli chodzi o kobiety, była matka. Przejawia się to w charakterystyce postaci Gertrudy, ale i dzieciobójczyń, którym poświęcił odrębną książkę ${ }^{15}$. Oświecenie było okresem, kiedy kształtował się nowy, bar-

11 P. Schmid, Weib oder Mensch, Wesen oder Wissen. Bürgerliche Theorien zur Weiblicher Bildung um 1800, w: Geschichte der Mädchen- und Frauenbildung, hg. E. Kleinau, K. Opitz, Frankfurt/New York 1996, Bd. 1, s. 340.

\footnotetext{
12 Ibidem, s. 327-329, 341; C. Opitz, w: Geschichte der Mädchen-..., Bd. 1, s. 18-19.

13 P. Schmid, Weib oder Mensch..., Bd. 1, s. 328-330.

14 Ibidem, s. 331-332.

15 Ibidem, .s. 340.
} 
dziej emocjonalny obraz relacji płci, miłość, która wyznaczała kobiecie miejsce strony biernej i adorowanej.

Ostatecznie mentalność mieszczańska i kapitalistyczna przeznaczyła mężczyźnie rolę „odpowiedzialnego” i zarabiającego „opiekuna”, w zamian za co kobieta winna mu była posłuszeństwo - tak to zostało klarownie ukazane we francuskiem Kodeksie Napoleona. Umocniona na nowo została rola matki (Rousseau, Campe), bardzo osłabiona przez arystokrację, ponownie wkładająca kobiecie buty tradycyjnych ról na łonie rodziny. Popularny pruski medyk Christoph Wilhelm Hufeland pisał w traktacie mającym po $1799 \mathrm{r}$. dziesięć wydań o znaczeniu opieki matczynej nad umierającymi masowo niemowlętami, o właściwym zachowaniu kobiety w ciąży, konieczności naturalnego karmienia, a nie oddawania dziecka do mamki, jak dla wygody robiono dotąd, wychowaniu, ubieraniu dzieci i żywieniü ${ }^{16}$.

\section{Pruskie oświeceniowe reformy szkolnictwa a kobiety}

Oświeceniowe reformy szkolnictwa występowały zarówno w Prusach, jak i w Polsce, jednak w Polsce instytucje państwa miały, niestety - tak to trzeba trzeźwo określić - charakter szczątkowy, stąd siła zmian w państwie Hohenzollernów była nieporównanie większa. Jeżeli w Rzeczypospolitej w 1772 r. utworzono Komisję Edukacji Narodowej, w Prusach 1787 r. utworzone zostało Naczelne Kolegium Szkolne - de facto ministerstwo szkolnictwa. Powszechne Pruskie Prawo Krajowe z 1794 r. określało wyraźnie, że szkoły i uniwersytety są placówkami państwowymi, a młodzież - także dziewczęta - objęta jest obowiązkiem szkolnym. W państwach oświeconego absolutyzmu, jak Prusy i też Austria, szkolnictwo uznane zostało za istotny sektor oddziaływania państwa na rozwój kraju, za czym szły też środki finansowe. Coraz większą rolę przy awansach w instytucjach publicznych odgrywało kryterium wykształcenia, zamiast urodzenia, a więc rosła liczba mieszczan na stanowiskach wyższego szczebla ${ }^{17}$. Pruskie władze oświatowe widziały cel kształcenia w przysposobieniu ucznia do jego przeznaczenia i wypełniania zadań życiowych. Tak też to ujmował członek Naczelnego Kolegium Szkolnego, Andreas Jakob Hecker w 1799 r. Uczeń był definiowany jako „człowiek” i ,obywatel” (Bürger), należący do określonego stanu i posiadający płeć społeczną. Minister edukacji Julius Massow pisał właśnie o wiedzy koniecznej dla określonego stanu i płci ${ }^{18}$. Definiowano jedynie specyficzną edukację dziewcząt, którą uważano za bardzo ważną dla państwa i społeczeństwa, uważając wykształcenie mężczyzn za zbyt oczywiste, aby

${ }^{16}$ S. Toppe, Mutterschaft und Erziehung zur Mütterlichkeit in der zweiten Hälfte des 18. Jahrhunderts, w: Geschichte der Mädchen-, Bd.1, s. 346-351.

${ }_{17}$ B. Zymek, G. Neghabian, Sozialgeschichte und Statistik des Mädchenschulwesens in den deutschen Staaten 1800-1945, Göttingen 2005, s. 28-29; K.-E. Jeismann, Preussische Bildungspolitik vom ausgehenden 18. bis zur Mitte des 19. Jahrhunderts, w: Zur Bildungs- und Schulgeschichte Preussens, hg. U. Arnold, Lüneburg 1988, s. 9-13.

18 D. Wagner, Mädchenbildung als Objekt staatlicher Reformpolitik. Preußen und Österreich 1780-1806, Trier 2010, E-BOOK, s. 19-20. 
trzeba było się nad tym rozwodzić. Hecker określał więc, że dziewczęta muszą otrzymać wykształcenie konieczne dla żony i matki. Kluczowe zadanie kobiety to rodzenie dzieci i opieka nad nimi, przynajmniej w pierwszych latach życia, potem związek z mężem miłość i przyjaźń, i towarzyszenie mu w troskach i niedolach. Rodzina stanowiła ramy działania dla kobiety. Ich życie nie miało sensu autotelicznego i było podporządkowane sprawom dzieci, męża i rodziny. Nie było mowy o indywidualnych zainteresowaniach, lecz podporządkowaniu interesom rodziny, stanu i państwa. Mieszanie się kobiet w męskie sprawy uważano za odejście od przeznaczenia własnej płci. Zła edukacja mogła sprowadzić dziewczęta nawet na drogę nierządu. W wypadku chłopów czy mieszczan obawiano się, że nadmierna edukacja spowoduje, że wyjdą oni poza obowiązki swojej klasy społecznej, w odniesieniu do dziewcząt chodziło o obowiązki płci. Z różnic fizycznych wywodzono różnice psychiczne i mniejszą zdolność do uczenia się. Wyraźne są pokrewieństwa i związki tej wizji zadań kobiety z wyobrażeniami współczesnych wpływowych myślicieli oświeceniowych - jak Rousseau i Campe. Jeszcze minister edukacji Karl Abraham von Zedlitz w 1770 r. uważał, że dla szlachcianek i mieszczanek edukacja powinna mieć różny charakter. Massow w 1799 r. uznawał już konieczność jednolitego dla wszystkich systemu ${ }^{19}$.

W Brandenburgii czy na Pomorzu protestantyzm już w XVI w. wprowadził jako normę edukację dziewczynek w szkołach elementarnych, kiedy w katolickich zaczęło się to upowszechniać dopiero w połowie wieku XVIII ${ }^{20}$. Do szkół niższych w Prusach uczęszczali więc teoretycznie zarówno chłopcy, jak i dziewczęta, ale brakuje dokładnych weryfikacji tej oceny. Do 13-14 roku życia uczono się za czesne przede wszystkim religii, czytania, pisania i rachunków. Pod koniec stulecia pojawiły się niezrealizowane plany reform Zedlitza i Massowa, gdzie przewidywano dla chłopców bardziej rozszerzony program nauczania, dziewczynki miały się nadal uczyć przede wszystkim czytania i religii ${ }^{21}$. Problemem były pieniądze - jak i dotąd, gdzie pensje nauczycieli były bardzo niskie, nie tylko w Prusach Południowych, ale i Brandenburgii, kiepski był stan budynków szkolnych. W 1770 r. w Brandenburgii Fryderyk II przeznaczył 100 tys. rtl. na wzorcowe szkoły państwowe dla biednych dzieci, tzw. szkoły łaski. Pieniądze wpłacono do banku, a odsetki zostały przeznaczone na wysokie pensje dla nauczycieli 120 rtl., gdzie większość w prowincji zarabiała $40 \mathrm{rtl} .^{22}$

Lepsza była sytuacja w miastach, gdzie projekty Zedlitza (1786) i Massowa (1796) analizowały braki w zakresie edukacji żeńskiej, zwłaszcza w małych miastach. Niejednokrotnie dziewczynki nie potrafiły nawet pisać i jedynie „trochę bazgroliły”. Rachunków nie uczono, a główna nauka jaką uczennica wynosiła ze szkoły to, żeby cicho siedzieć na lekcji. Zedlitz krytykował też nadmiar niepotrzebnej dzieciom z niższych stanów łaciny i brak w programie wiedzy praktycznej. Prowadziło to mieszczan do niepotrzebnych ambicji studiowania i następnie porzucaniu fachu ojca oraz nieadekwatnego do przyszłe-

\footnotetext{
19 Ibidem, s. 21-30.

${ }^{20}$ H. Heppe, Geschichte des deutschen Volksschulwesens, Gotha 1858, Bd. 3, s. 4.

${ }^{21}$ D. Wagner, Mädchenbildung als Objekt staatlicher Reformpolitik, s. 31-34.

22 Ibidem, s. 36-39.
} 
go życia żony i matki edukowania dziewcząt. Lepiej już, żeby nie umiały nic poza pracami domowymi. Zamiast łaciny i antyku zalecał nauczanie historii ojczystej, geografii, historii naturalnej, nauki moralnej, znajomości rzemiosł i fizyki ${ }^{23}$.

Plany Massowa, Gedikego, czy Steinbarta albo Heckera - którzy byli zarazem wysokimi urzędnikami albo wpływowymi postaciami w Prusach - powołania podzielonych na szczeble średnich koedukacyjnych „szkół obywatelskich” (Bürgerschule), i szkół dla dziewcząt obejmowały również edukację dziewcząt. Szkoły te miały mieć znacznie bardziej praktyczny i zawodowy charakter niż szkoły łacińskie i były pomyślane dla przyszłych mieszczan, rzemieślników, kupców itp. Częściowo stanowić miały też przygotowanie do gimnazjum. W zakresie języków obcych mówiło się o przygotowaniu w językach - francuskim, łacinie, ale także polskim. Taki był program dla chłopców - dla dziewcząt wyłączona była łacina - bo nie miały wstępu do szkół gimnazjalnych, oraz przedmioty zawodowe kupieckie ${ }^{24}$. Hecker uważał, że w szkołach średnich powinny uczyć się wyłącznie dziewczęta bogatszej klasy średniej (Mittelstand): w programie umieścił ważny dla dam język francuski, dla „uformowania serca” - religię, widział też perspektywę „kształtowania charakteru” i „kształtowania ducha”. Za niezbędne dla dziewcząt przedmioty uważał: naukę czytania, pisania, rachunków, język niemiecki, francuski, historię naturalną, naukę moralną, geografię i historię ojczyzny, dietetykę, prace kobiece, znajomość rzemiosł i towarów. Pożyteczna, ale nie niezbędna wydała mu się też znajomość literatury niemieckiej, przyrody, historia i geografia powszechna, anatomia i fizjologia, rysunki, malarstwo i muzyka ${ }^{25}$.,Szkoły przemysłowe”, także nowy koedukacyjny projekt przełomu wieków (Industrieschule) miały być szkołami, ,zwalczającymi próżniactwo" klas niższych, przygotowującymi do pracy w rzemiośle, z podziałem na część szkolną i przysposobienia do pracy. Dzieci uczyły się szyć, prząść, dziergać, sadzić drzewka i hodować pszczoły i jedwabniki. Praca dzieci nie budziła zdziwienia i była normą w tym czasie. Przeciwnicy pomysłu tych szkół wskazywali, że dzieci i bez tego są przyuczane do pracy w gospodarstwie. W Brandenburgii „,szkoły przemysłowe” zaczęły być organizowane zarówno na wsi, jak i w mieście już od 1790 r. ze wsparciem finansowym państwa. Wśród uczniów dominowały dziewczynki. W samym Berlinie w 1800 r. było dziewięć placówek z 560 uczniami, z czego 73\% dziewczynek, a szkoły takie istniały również $\mathrm{w}$ małych miastach ${ }^{26}$.

Istniały też koedukacyjne szkoły prywatne, finansowane wyłącznie z czesnego, gdzie uczyły się również dziewczęta, których nie uczono łaciny, a raczej język francuski. W szkole we Frankfurcie n. O. uczono 20-40 dziewcząt w 1799 r. religii, rachunków, pisania, prac kobiecych, języka niemieckiego, francuskiego, nauki moralnej, historii świata, geografii, rysunków, historii państw europejskich, śpiewu, rzemiosła, poezji i zoologii. Szkoła była dofinansowywana przez państwo ${ }^{27}$.

\footnotetext{
23 Ibidem, s. 41-43.

${ }^{24}$ Ibidem, s. 63-64.

25 Ibidem, s. 65-66.

${ }^{26}$ Ibidem, s. 76-88.

27 Ibidem, s. 68-71.
} 
Nauczanie domowe dziewcząt było w Prusach zjawiskiem wśród szlachty i zamożnego mieszczaństwa częstym, a zdarzało się i wśród mniej zamożnego mieszczaństwa. Związane to było też z poglądem, że dziewczynki nie powinny się uczyć poza domem. Pedagodzy oświeceniowi wprawdzie już ten pogląd ostro krytykowali jako anachronizm. Uważano także, że łacińskie szkoły miejskie są na marnym poziomie i uczą rzeczy zbędnych albo anachronicznych, a zawsze nauczanie domowe uważane było za równoważne ze szkolnym. Rosła liczba szkół dla dziewcząt, a wraz z tym liczba kobiet zdatnych do pracy jako nauczycielki domowe. W 1803 r. powstało na przykład Królewskie Seminarium dla Wychowawczyń w Berlinie. W nauczaniu domowym podstawową rolę odgrywał język francuski, który w tym czasie znać powinna każda dama. Bardzo często guwernerkami były Francuzki, w protestanckich Prusach przede wszystkim imigrantki hugenotki. Katolickie rodziny sprowadzały nauczycielki nierzadko z Francji. Massow $\mathrm{w}$ swoich niezrealizowanych projektach planował podporządkowanie nauczycieli prywatnych, państwowym egzaminom ${ }^{28}$. Młode dziewczęta musiały mieć nie tylko francuskie guwernantki, ale i fryzjerów i nauczycieli tańca, by całkiem upodobnić się do dam królewskiego dworu. Elity naśladował na miarę swoich możliwości lud i zdarzało się, że rzemieślnicy i dzierżawcy rujnowali się na francuskiego guwernera. Mówiła po francusku $i$ włosku, była muzykalna, miała wdzięczny głos i dobrze grała na kilku instrumentach - powiadano o dobrze wykształconej pruskiej szlachciance. W Gdańsku francuskie mamzele owych czasów, tak bowiem ogólnie guwernantki nazywano, byty wszystkie urodzonymi berliniankami z francuskiej kolonii - pisała Joanna Schopenhauer. Podobnie Marwitz pisał eine französische Mamsell, o guwernantce z kolonii berlińskiej, którą otrzymał wraz z siostrą w wieku czterech lat ${ }^{29}$.

Poglądy bywalczyń berlińskich salonów w początku XIX w., takich jak żona Georga Forstera - Teresa, córka Mosesa Mendelsohna - Dorothea Veit, czy żona Schlegla - Carolina Böhmer, były oświecone i całkiem podobne, i nie ograniczały się tylko do kręgu tych kobiet. Wiek Oświecenia przyniósł znaczną aktywizację ambicji edukacyjnych i intelektualnych mieszczanek i szlachcianek, i pewną akceptację wykształconego mieszczaństwa dla tych poglądów. Skończyło się to jednak po 1815 r., kiedy wraz z romantyzmem i kapitalizmem powróciły stosunki patriarchalne. Joanna Schopenhauer mówiła, że dziewczynka zbyt wykształcona uważana była za osobe przesadna i dziwaczna, niekorzystny typ młodej, uczonej damy ${ }^{30}$. Jak wiadomo wstęp na uniwersytety w Niemczech

${ }^{28}$ I. Hardach-Pinke, Erziehung und Unterricht durch Gouvernanten, w: Geschichte der Mädchen..., Bd. 1, s. 409-410, 417, 423, 425. D. Wagner, Mädchenbildung als Objekt staatlicher Reformpolitik..., s. 73-74.

${ }^{29}$ Duc de Lauzun, Pamiętniki, Warszawa 1976, s. 155; M. von Boehn, Die Mode. Eine Kulturgeschichte vom Barock bis zum Jugendstil, München 1989, Bd.2, s. 8-14; J. Scherr, Deutsche Kultur- und Sittengeschichte, Leipzig b.d., s. 458; F.S. Pierre Dufour, Historia prostytucji od czasów najdawniejszych do XX w., Gdynia 1998, t. 3, 281-316; J. Schopenhauer, Gdańskie wspomnienia młodości, Gdańsk 2010, s. 133; W. Neugebauer, Absolutistischer Staat..., s. 603-611; F. A. Ludwig von der Marwitz, Ein märkischer Edelmann im Zeitalter der Befreiungskriege, Berlin 1908, Bd.1, s. 20-21, 36, 44; M. Burleigh, Ziemska władza. Polityka jako religia, Warszawa 2011, s. 57-58.

${ }^{30}$ H. Arendt, Rahel Varnhagen. Historia życia niemieckiej Żydówki z epoki romantyzmu, Sejny 2012, s. 52-54; 81-85; B. Beyus, Familienleben in Deutschland, Reinbeck 1988, s. 389-390, 424; U. Frevert, Mą̇ i niewiasta. Niewiasta i mąż. O różnicach płci w czasach nowoczesnych, Warszawa 1997, s. 61-82, 145-158, 
dziewczęta otrzymały dopiero w 1900 r., ale w okresie Oświecenia pewna ich grupa, raczej jednostki, studiowały jednak poza obowiązującym porządkiem. Należała do nich Dorothea Christiane Erxleben (1715-1762), Dorothea Schlözer (1770-1825), Anna Balthasar (1737-1808). Oczywiście nawet wśród kobiet powszechny był pogląd Christiane Mariane Ziegler z 1739 r., że jej koleżanki nie mają zdolności intelektualnych do studiów i nadają się do prac domowych ${ }^{31}$.

Arystokracja pruska, podobnie jak polska, rozmawiała zwykle między sobą po niemiecku, ale zawsze wtrącała francuskie słówka, które nadawały rozmowie „wytwornego" charakteru. Dominowała szkolna znajomość, wystarczająca do porozumienia się. $W$ domu moich rodziców stale mówiło się po francusku, jak $i w$ wszystkich innych domach $w$ tym czasie, z którymi mieliśmy kontakt - wspominał berliński szlachcic Friedrich Marwitz. Gdańszczankę, Joannę Schopenhauer rodzice w domu nazywali snobistycznie z francuska Jeanette. Kiedy uczyła się języka angielskiego, całe otoczenie dziwiło się, że jest to dla dziewczynki język nieodpowiedni i niepotrzebny. Zaczęłam się w końcu wstydzić mojej znajomości angielskiego - pisała Joanna. Szczególnie silne były wpływy francuskie na berlińskim dworze i wśród szlachty od czasów Fryderyka II, ceniącego wyłącznie kulturę francuską, do czego przyczyniała się też obecność licznych francuskich kolonistów. Było wśród nich wielu kupców, co powodowało, że w licznych berlińskich sklepach mówiło się po francusku, liczne były pochodzące $\mathrm{z}$ tego środowiska guwernantki. Koloniści mówili już wprawdzie po niemiecku, ale źle i z akcentem ${ }^{32}$.

\section{Edukacja pod zaborem pruskim (Prusy Południowe)}

W niniejszym tekście zajmuję się jedynie prowincją Prusy Południowe, czyli ziemiami zagarniętymi na skutek II i III rozbioru, a więc - rzecz ujmując z grubsza - Wielkopolską i Mazowszem ${ }^{33}$. Podobnie jak w całych Prusach, również na ziemiach polskich Prusacy uważali za konieczną edukację kobiet jedynie dla rodziny, do roli matki i żony.

182, 253, 258; G.A. Craig, Über die Deutschen, München 1991, s. 170-171; M. Michael, Die Biographie des Bürgers. Lebensformen und Denkweisen in der formativen Phase des deutschen Bürgertums (1680-1815), Göttingen 1996, s. 539-548; Th. Nipperdey, Deutsche Geschichte 1800-1866. Bürgerwelt und starker Staat, München 1983, s. 119-120; H. Glaser, Industriekultur und Alltagsleben. Vom Biedermeier zur Postmoderne, Frankfurt a. M. 1994, s. 124-125; A. Gestricht, Neuzeit, w: Geschichte der Familie, Stuttgart 2003, s. 377; D. Sdvižkov, Epoka inteligencji. Historia porównawcza warstwy wykształconej w Europie, Warszawa 2011, s. 104-105, 113; I. Weber-Kellermann, Frauenleben im 19. Jahrhundert. Empire und Romantik, Biedermeier, Gründerzeit, München 1985, s. 31; U. Frevert, Frauen-Geschichte zwischen Bürgerlicher Verbeßerung und Neuer Weiblichkeit, Frankfurt a.M. 1986, s. 98-99; U. Baumann, Protestantismus und Frauenemanzipation in Deutschland 1850 bis 1920, Frankfurt/New York, 1992, s. 14-15; J. Schopenhauer, Gdańskie wspomnienia młodości, Gdańsk 2010, s. 118.

31 B. Niemeyer, Ausschluss oder Ausgrenzung. Frauen im Ukreis der Universitäten im 18. Jahrhudnert, Geschichte der Mädchen-..., Bd. 1, s. 275, 279-281.

${ }^{32}$ I. Krasicki, Uwagi, Warszawa 1997, s. 328, 332-333; T. Veblen, Teoria klasy próżniaczej, Warszawa 1998, s. 136-141.

33 Ogólna charakterystyka szkolnictwa południowopruskiego, D. Lukasiewicz, Szkolnictwo w Prusach Potudniowych (1793-1806) w okresie reform oświeceniowych, Warszawa-Poznań 2004. 
W związku z tym edukację szlachcianek do ,życia światowego” uważano za niewskazaną. Znacząca jest tu wymowa memoriału radcy wojennego Schirrmeistera (niestety brak imienia) z Płocka do ministra Schröttera z 1800 r. ${ }^{34}$ Jak powiada ówże, już dawno przenikliwi obserwatorzy ludzkich spraw zauważyli, że te narody, które „z pewną rezygnacją" w ich religii oddają cześć żeńskim bóstwom (kult maryjny), również w świeckich sprawach poświęcają płci przeciwnej szczególną uwagę i pozwalają jej sobą kierować. Jak dowodzi Schirrmeister, sytuacja taka miała mieć miejsce w krajach katolickich, w tym i w Polsce. Mieć tam miało miejsce specyficzne poddanie duchowe mężczyzn kobietom. Mężczyzna ofiarowywał kobietom zarówno swoją wolę, jak i rozum tak w sprawach domowych, jak i w kwestii interesów. Wskazuje tu z jednej strony na nieosiągającą jeszcze francuskiego poziomu galanterię i kurtuazję wobec kobiet, z drugiej na hołdy składane świętym niewiastom. Schirrmeister sądził, że przyznawanie płci żeńskiej przewagi w zakresie talentu i ,przyjemnych przymiotów ducha” nie przynosi mężczyznom w Polsce ujmy na honorze, jest natomiast zupełnie niezrozumiałe, że przy wszystkich tych hołdach nie robi się niczego dla publicznej edukacji kobiet. Poprzestaje się na tym, że ,wielcy i bogaci” dochodzą do przesady w ,światowym” kształceniu swoich córek, wiernie kopiując francuskie ideały i praktykują je pod nazwą „,dobrego tonu i dobrego smaku" równie rozrzutnie i zarozumiale, jak rodowite Francuzki, odgrywając w zależności od okoliczności kokieterię lub pruderię, bez dogłębnej znajomości spraw, mieszając się do spraw publicznych. Towarzysząca temu bezmierna gadatliwość, dziwił się Schirrmeister, spotyka się z uznaniem mężczyzn. Wychowanie to prowadzi do swobody obyczajów, zamiłowania do tańców, przy jednoczesnym braku gospodarności ${ }^{35}$.

W podobnym duchu o wychowaniu panien pisał Friedrich Schulz, który poznał nieco lepiej Warszawę na progu rozbiorów: Pierwszym jego celem uczynić je pięknymi, miłymi i petnymi uroku. Cnoty matki i żony pozostawia się do wyrobienia okolicznościom, które przy reszcie serca i uczucia, jakie im eleganckie wychowanie zostawi, albo potem się rozwina lub znikna. W tym względzie młode panienki nie otrzymuja nauk, a dobrych przykładów mają mało. Plamka na twarzy lub na ręku więcej niepokoi czuła matkę jak wada umystu, a mała cielesna ułomność mocniej niż serca kalectwo ${ }^{36}$. Z Polaków w ten sposób pisał Alojzy Osiński w 1801 r.: Znałem matke, mówi P. Soret, przestrzegająca córkę sto razy na dzień, aby się prosto trzymała, a nigdym jej nie styszat, zalecajacej skromna obyczajów niewinność. W jednej ręce moralność z katechizmem, a $w$ drugiej z galanterią. Moralista współczesny dobrze dat uczuć śmieszność edukacji kobiecej. Trzymaj się prosto, rzekt, schylasz się na bok, chodzisz skrzywiona. Podnieś swa głowę, mile poglądaj, nie dotykaj się twarzy, gdzie twoje sa ręce, trzymaj nogi naprzód, ułóż swoje ramiona. Oto moralność w przeciagu lat 12 lub 15. Wielu matek wcale podobne postępki: każa się tylko wszystkim podobać i łudzić zwierzchnia obłuda, nie pomnę by-

34 P. Schwartz, Die preußische Schulpolitik in den Provinzen Südpreußen und Neuostpreussen (1795-1806), „Zeitschrift für Geschichte der Erziehung und des Unterrichts” 3, 1911, s. 141-142.

35 Ibidem, s. 141-142.

${ }^{36}$ F. Schulz, Podróże Inflantczyka z Rygi do Warszawy i po Polsce w latach 1791-1793, Warszawa 1956, s. 249 . 
najmniej na tę najprawdziwsza moralności przestrogę: że powierzchowność znikoma, a grunt poczciwego serca całego życia jest okrasa. Ustawicznie zatrudnione robotami $w$ swych oknach i czytaniem romansów $w$ tysięczne przebieraja się barwy dla zwrócenia oczu na siebie. Oto geniusz kobiet! Śpiewać pięknie, tańczyć, stroić się modnie, ujmujacym tonem przemawiać i misterne robić ukłony, to grunt edukacji kobiecej ${ }^{37}$. Rzecz jasna w następnej kolejności Osiński sławi wzór kobiety skromnej, gospodarnej i zajętej wychowywaniem dzieci.

W 1804 r. radca Fischer krytykował prywatne pensje dla dziewcząt w Warszawie: O wyksztatcenie dziewcząt na matki i panie domu nie ma troski w prawie żadnym z tych Instytutów. Wszystkie w mniejszym lub większym stopniu przejawiaja tendencje wychowywania powierzonej im młodzieży tylko dla świata, a nie dla kręgu rodziny ${ }^{38}$. Za lepiej urządzone uważał Fischer pensje Peters, Delreux, Redla, de la Casa i Wrzesińskiej. Poglądy Fischera, nie tak rzadkie w pruskich kręgach urzędniczych, zmierzały do konkluzji, że kobiety ze sfer szlacheckich „wychowane do życia światowego” niepotrzebnie mieszały się w politykę i przez swój w niej udział przyczyniły się do katastrofy państwa polskiego ${ }^{39}$.

Jak stwierdzał dalej Fischer, osobliwością szlachty polskiej było przywiązywanie większej wagi do wychowywania córek niż synów. Błędne wychowanie dziewcząt, nie odpowiadające ich przyszłemu powołaniu, nie było jednak winą rodziców, a nauczycielek, które same nie miały żadnego przygotowania pedagogicznego. Reforma edukacji żeńskiej powinna się więc zacząć od utworzenia seminarium kształcącego nauczycielki. $\mathrm{Na}$ ten cel proponował przeznaczyć prywatną pensję Valentine Peters, która posiadała odpowiedni budynek i ogród pozwalający na nauczanie o roślinach, a sama Peters miała jego zdaniem odpowiednie, wysokie kwalifikacje. W szkole tej kształcić miano 4 dziewczęta w wieku 15-20 lat, na których edukację państwo łożyłoby co roku 50 rtl. Przypomnijmy, że w seminarium nauczycielskim dla chłopców stypendium wynosiło $100 \mathrm{rtl}$. Nadzór nad seminarium sprawować miał tzw. eforat, złożony z dam warszawskich pochodzenia niemieckiego i polskiego.

Opinie Fischera i Schirrmeistera na temat nadmiernego mieszania się dam polskich do polityki i dawania im wychowywania nieodpowiadającego kobietom, nie były bynajmniej pruską fanaberią ${ }^{40}$. To samo u nas pisał Hugo Kołłątaj ${ }^{41}$, Jędrzej Kitowicz ${ }^{42}$ i Ignacy Krasicki. Ten ostatni wywodził, mając na myśli przypisane ówcześnie płci niewieściej

${ }^{37}$ A. Osiński, Nauka oyca dana synowi, Warszawa 1801, s. 67-68.

${ }_{38}$ RWD (Radca Wojenny i Domenalny) Fischer do PDF, Warszawa 5.07.1804, AGAD, GDPP, VI 3540, k.10-15; por. Raport Fischera o pensjach, Warszawa 11.04.1804, AGAD, GDPP, VI 3540, k. 16-17.

39 Uwagi pruskie o wychowaniu szlachcianek do ,życia światowego” i o ich zainteresowaniach wybiegających poza życie rodzinne znajdują potwierdzenie w uwagach Hugona Kołłątaja, który bardzo wysoko oceniał poziom ich edukacji, zob. H. Kołłątaj, Stan oświecenia w Polsce w ostatnich latach panowania Augusta III (1750-1764), Wrocław 1953, s. 136.

${ }^{40} \mathrm{O}$ zaangażowaniu kobiet epoki oświecenia w politykę zob. J. Skowronek, Debiuty polityczne kobiet..., s. 29-41; M. Bogucka, Białogłowa $w$ dawnej Polsce..., s. 213-220.

${ }^{41}$ H. Kołłątej, Stan oświecenia w Polsce..., s. 136; idem, O języku ojczystym, teatrze i edukacji, s. 78.

42 J. Kitowicz, Pamiętniki czyli historia Polska, Warszawa 1971, s. 488. 
dyspozycje: Gdy Henrykowi IV, królowi francuskiemu, podat krawiec projekt o sądach, kazał zawołać kanclerza wielkiego, aby mu wzią miarę na sukniq. Trzeba się każdemu zatrudniać tym, co zdoła, со mu należy i co mu przystoi ${ }^{43}$. Następnie poważnie wywodzi Krasicki, jak fatalnie szkodzi kobietom na urodę zaangażowanie w naukę i politykę: zbytnie zacieczenie się $w$ naukach, bohatyrstwo i statystyczne perory ksztaltowi, delikatności, wdziękom i świeżości szkodza ${ }^{44}$. Ostatecznie, zmierzając do celu, dowodzi: Istotnym celem wychowania panieńskiego powinien być ich stan przyszly matżonek i matek ${ }^{45}$. Takie same krytyki wychowania dziewcząt jedynie do „obejścia towarzyskiego” wyszły spod pióra Fryderyka Skarbka, który rozwodził się też nad ich zamiłowaniem do kultury francuskiej: Kobiety uchodzity za literatki, gdy znaly arcydzieta literatury francuskiej, za filozofki gdy czytaty Woltera a nade wszystko „Emila” Roussa, który zawracal głowy egzaltowanych matek do tego stopnia, iz niektóre wychowywaty synów podlug zasad tego filozofa. Nadto nowa Heloiza przyczyniała się do rozwijania romansowych sktonności kobiet naszych i doprowadzała je obok wplywu catkiem francuskiego wychowania do egzaltacji, która się stała źródtem wielu nieszczęść domowych ${ }^{46}$.

Jean Bugwoy podobnie chwalił znajomość języków u polskich dam, ale jak dowodził czytają w nich jedynie modną dowcipną literaturę, a pod nieobecność mężów i przy wielkim wpływie, jaki na nich mają, prowadzą domowe interesy ${ }^{47}$.

W memoriale z 1800 r., Fischer zwrócił uwagę na potrzebę zakładania w miastach szkół przemysłowych, które miały edukować mieszczan w zakresie prac ręcznych. Uważał to za szczególnie wskazane w stosunku do kobiet ${ }^{48}$. Jak pisał: nigdzie nie sa kobiety z niższego stanu mniej zajęte niż tutaj, w Prusach Poludniowych $i$ stąd znajduje się wśród nich wszelkie skutki próżnowania, a przede wszystkim powszechna skłonność do pijaństwa. Widok rojacych się pijanych kobiet $i$ dziewczat $w$ tutejszych szynkach jest czymś calkiem zwyklym ${ }^{49}$. Jak stwierdzał dalej zaniedbanie wychowania dziewcząt jest głównym powodem upadku moralnego i nędzy Polaków. Sposobem zaradzenia temu stanowi rzeczy byłoby więc zakładanie szkół, w których kobiety uczyłyby się szyć, prząść, robić na drutach etc. Miałoby to też dać ich rodzinom dodatkowe źródła dochodu.

Obserwacji socjologicznej Fischera należy poświęcić nieco uwagi. Jak zwykle uwidacznia się w niej przemożna niechęć do Polaków. Można z niej też jednak odczytać informację o większej swobodzie kobiet z ludu w Polsce niż w Prusach, ale taka interpretacja wydaje się nie dość precyzyjna. Fischer swoje doświadczenia czerpał z egzystencji w Warszawie, gdzie wśród elit panowały inne stosunki niż w grupach średnioza-

43 I. Krasicki, Uwagi, s. 42.

44 Ibidem, s. 43.

45 Ibidem, s. 170.

${ }^{46}$ F. Skarbek, Olim, Berlin-Poznań 1866, s. 227, 233-234; por. K. Morawski, Ze studiów nad kobieta polska w XVIII wieku, s. 31-42.

47 J. Bugwoy, Pohlen nach seiner bisherigen geographischen, politischen, statistischen, physikalischen und kirchlichen Beschaffenheit, Bunzlau 1796, s. 91.

${ }^{48}$ Fischer, KWD w Warszawie do PDF, Warszawa 26.01.1800 r., AGAD, GDPP, I 1598, k. 12-19.

49 Podobnie F. Schulz, Podróże Inflantczyka, s. 193. 
możnych. Z kolei obyczajowość ludowa nie poddana tak gorsetowi moralności religijnej również była dosyć swobodna.

$\mathrm{W}$ istocie rzeczy, jeżeli państwo pruskie przejawiało jakieś zainteresowanie dla edukacji kobiet, to odnosiło się ono przede wszystkim do szkolnictwa niższego ${ }^{50}$ i miało na celu lepsze przygotowanie kobiet do pełnienia przez nich roli żony i matki.

Młodzież polska z salonów wychowywana przez francuskich guwernerów nie miała pojęcia o historii Polski i polskiej literaturze, i od rodziców też się jej nie mogła nauczyć. Franciszek Gajewski wspominał, że: panowie guwernerowie [...] ciagle nam tylko o Francji pletli $i$ wbijali w pamięć dzieje narodu francuskiego. Na nauczycieli francuskich był tak wielki popyt, że szlachta rywalizowała ze sobą o przybywających do Polski Francuzów i sprowadzała ich aż z Niemiec i Francji, a często zatrudniała księży emigrantów. Byli to w większości ludzie, którzy o edukacji nie mieli żadnego pojęcia, najczęściej nie znali języka polskiego i jedyną ich kwalifikacją było pochodzenie narodowe - tak to oceniał guwerner francuski Hubert Vautrin. Wawrzyniec Surowiecki rozpaczał w 1806 r. nad dokonującym się wynarodowieniem dzieci szlacheckich i zachęcał rodziców, by wysyłali dzieci do pruskiego gimnazjum w Warszawie pielęgnującego mowę ojczystą, poświęcającego czas dziejom Rzeczypospolitej i jej geografii. Podobnie Fryderyk Skarbek wspominał, że francuscy guwernerzy kształcili polska młodzież na owych gładkich trefnisiów, co po francusku niewiastom słodkie stówka prawić, lub z niemi na wzór starożytnej galanterii francuskiej rozprawiać i pieszczone ich klasyków wiersze cytować umieli, a w zupełnym zaniedbaniu był język niemiecki, w ówczesnych stosunkach $i$ do prawdziwego oświecenia dla nas zwłaszcza niezbędnie potrzebny ${ }^{51}$. Stanisław Litak wspomina o nauczycielach domowych nauczania elementarnego nawet u drobnej szlachty, mieszczan i najzamożniejszych chłopów. Istniało też wzajemne nauczanie po domach w niedziele i święta ${ }^{52}$.

\footnotetext{
${ }^{50} \mathrm{O}$ braku zainteresowania państwa dla prywatnych pensji żeńskich zob. W. Neugebauer, Absolutistischer Staat..., s. 622-623.

51 D. Rolnik, Portret szlachty czasów stanisławowskich ..., s. 172-174.

${ }^{52}$ W. Molik, Rozrzutność i oszczędność ziemiaństwa polskiego w zaborze pruskim $w$ XIX i na początku XX wieku, w: Rozrzutność i skapstwo w tradycji kulturowej i rzeczywistości, red. J. Tazbir, Kraków 2005, s. 133-155; F. Skarbek, Pamiętniki, Warszawa 2009, s. 69-81; H. Kołłątaj, Stan oświecenia w Polsce..., Wrocław 1953, s. 13-14; J. Kitowicz, Opis obyczajów za panowania Augusta III, Warszawa 1985, s. 56; Z. Chyra, Nauczyciele prywatni (1764-1807), w: Spoleczeństwo polski XVIII i XIX wieku, red. J. Leskiewiczowa, Warszawa 1974, T. 6, s. 10; R. Wołoszyński, Między tradycją i reformą. Nauczyciele w Polsce XVIII wieku, Piotrków Trybunalski 2002, s. 204-209; F. Skarbek, Pamiętniki Seglasa, Warszawa 1959, s. 7-8; J. Kosim, Pod pruskim zaborem. Warszawa w latach 1796-1806, Warszawa 1980, s. 116; W. Surowiecki, List do przyjaciela mieszkajacego nad rzeka Warta o wadach edukacji młodzieży polskiej, Warszawa 1806, s. 13-29; K. Koźmian, Pamiętniki, t. 1, Wrocław 1972, s. 175-178; F. Skarbek, Olim, s. 7-8, 227; F. Gajewski, Pamiętniki Franciszka z Błociszewa Gajewskiego pulkownika wojsk polskich (1802-1831), Poznań 1913, T. 1., s. 6; H. Vautrin, Obserwator w Polsce, w: Polska stanisławowska w oczach cudzoziemców, opr. W. Zawadzki, Warszawa 1963, T. 1, s. 792; M. Deszczyńska, Polskie kontroświecenie, Warszawa 2011, s. 68-86; J. Czubaty, Księstwo Warszawskie (1807-1815), Warszawa 2011, s. 43-46; J. Skowronek, Książę Józef Poniatowski, Wrocław 1984, s. 103-104; R. Bielecki, Ksiązę Józef Poniatowski, Warszawa 1974, s. 49-51; J. Kitowicz, Pamiętniki czyli historia Polska, s. 477-479; A. z Tyszkiewiczów Potocka-Wąsowiczowa, Wspomnienia naocznego świadka, Warszawa 1965, s. 31, 38-39; F. Skarbek, Dzieje Księstwa Warszawskiego, t. 1, b.d., s. 55-56, 63-64; J. Jedlicki, Jakiej cywilizacji Polacy potrzebują? Studia z dziejów idei i wyobraźni XIX wieku, Warszawa 1988, s. 24-31; I. Krasicki,
} 
Ważnym elementem edukacji zamożniejszej szlachty, przede wszystkim męskiej, były peregrynacje, a więc edukacyjne podróże za granicę, trwające czasem nawet kilka lat. Zdarzały się one jednak również damom. Edukację za granicą odbywała Apolonia Helena Massalaska (1771-1779). Podróżowała do Paryża i bez wytchnienia zwiedzała wszystko co było tego warte Wirydianna Fiszerowa ${ }^{53}$. Ważnym elementem edukacji była też domowa lektura piśmiennictwa przez młodzież, której analizą zajęła się Alina Hinc $^{54}$.

Edukacja kobiet polegała przede wszystkim na wpojeniu posłuszeństwa wobec rodziców, umiejętności obchodzenia się z mężem, posłuszeństwa i poddania wobec niego, a jednocześnie utrzymania go przy sobie, a potem przejęciu od matki znajomości prac gospodarskich - gotowania, prania czy szycia: pracowitość rzadnych matek, praktyka gospodarska byty ubogich wprawa panienek do takowego życia, na jakie poświęcać się musiały - pisał Hugo Kołłątaj. Ślady oświeceniowej emancypacji były w Polsce słabo widoczne $^{55}$. Do tego dochodziła pewna wiedza medyczna, dotycząca leków i ich stosowania, bardzo ważna socjalizacja religijna, potrzebna do wychowania dzieci, w wyższych stanach umiejętność czytania i pisania. Dopiero też mężatka uzyskiwała status pełnowartościowej spełnionej kobiety ${ }^{56}$. Do edukacji kobiecej należały także damskie cnoty, za jakie uważano pilność, pracowitość, oszczędność, dobroczynność, łagodność, cierpliwość. Jędrzej Kitowicz wspomina jeszcze, że dziewczęta oddawano też na naukę do „niewiast statecznych”, które uczyły je czytania po polsku, dziergania i szycia ${ }^{57}$. Nie wydaje się jednak, aby była to praktyka powszechna ${ }^{58}$.

Dla dziewcząt ze szlachty i zamożnego mieszczaństwa przeznaczone były prywatne pensje i klasztory, jednak jak sądzi Marianna Krupa trafiała tam tylko mniejsza część córek z wymienionych grup ${ }^{59}$. W istocie rzeczy nasza wiedza na temat edukacji klasztornej polskich dziewcząt jest jeszcze dosyć uboga. Wiemy, że ta forma nauczania była

Uwagi, s. 109-110, 162-170; Z. Ostrowska-Kłębowska, Architektura pałacowa drugiej połowy XVIII wieku w Wielkopolsce, Poznań 1969, s. 245-290.

53 A. H. Massalska, Pamiętniki pensjonarki. Zapiski z czasów edukacji w Paryżu (1771-1779), Kraków 2012; W. Fiszerowa, Dzieje moje własne, s. 32-37; D. Rolnik, Portret szlachty czasów stanisławowskich, s. $168-191$.

${ }^{54}$ A. Hinc, Obraz dziejów ojczystych w pozaszkolnej edukacji historycznej społeczeństwa polskiego w Wielkim Księstwie Poznańskim w pierwszej połowie XIX wieku, Poznań 2007.

${ }_{55}$ H. Kołłątaj, Stan oświecenia w Polsce, s. 133. R. Dürr, Von der Ausbildung zur Bildung. Erziehung zur Ehefrau und Hausmutter in der Frühen Neuzeit, w: Geschichte der Mädchen-..., Bd. 1, s. 189-193; I. Rusinowa, Ideaty wychowawcze kobiet..., s. 63-69.

56 R. Dür, Von der Ausbildung zur Bildung..., s. 193, 199-201.

57 J. Kitowicz, Opis obyczajów, s. 56.

58 Jak dowodzi V. Seibel również w Prusach edukowanie dziewcząt występowało rzadko, zob. Elternhaus, Schule, politische Ideen und Erfahrungswelt in den Generationen vor und nach 1800, Darmstadt 1986, s. 70,78 .

59 M. Krupa, Schulerziehung in Polen 1750-1825, w: Revolution des wissens? Europa und seine Schulen im Zeitalter der Aufklärung (1750-1825), red. W. Schmale, Bochum 1991, s. 376; M.M. Grzybowski, s. 19; I. Rusinowa, Ideały wychowawcze kobiet..., s. .63-64; S. Litak, Edukacja początkowa w polskich szkołach w XIII-XVIII wieku, Lublin 2010, s. 233-258; M. Borkowska, Życie codzienne polskich klasztorów żeńskich w XVII-XVIII wieku, Warszawa 1996. 
dosyć rozpowszechniona i w klasztorach uczyło się ok. 3000 dziewcząt, co jest bez wątpienia jedynie ogólnym szacunkiem ${ }^{60}$. Pruskie źródła urzędowe nie pozwalają niestety nic powiedzieć na temat żeńskiego szkolnictwa klasztornego. Papież Paweł V już w 1615 r. zalecał, aby w Zakonie Urszulanek prowadzona była edukacja sióstr, która miała obejmować ćwiczenie pobożności i cnoty, nauki chrześcijańskiej, śpiewu pieśni pobożnych, czytania i pisania oraz prac kobiecych. Te wyobrażenie odzwierciedlały ówczesne ambicja powszechnej religijnej i elementarnej edukacji dziewcząt, przygotowujące je do roli żony i matki ${ }^{61}$.

Poza klasztorami ważną formą edukacji kobiet były pensje dla dziewcząt. W departamencie kaliskim funkcjonowały dwie szkoły żeńskie: w Kłobucku uczono dziewczęta języka niemieckiego i polskiego oraz szycia i robienia na drutach. Ten sam program, pozbawiony jedynie języka niemieckiego obowiązywał w szkole w Koninie. W obydwu szkołach nie było nauki rachunków ${ }^{62}$.

W departamencie warszawskim Prusacy odnotowali działalność szkoły żeńskiej w Stefanowie, w powiecie czerskim, gdzie dziewczęta uczono jedynie czytania i pisania $^{63}$. W Łęczycy funkcjonował instytut dla dziewcząt prowadzony przez żonę fizyka powiatowego Mauersbergera. Został on wysoko oceniony przez Gedikego podczas wizytacji w 1802 r. $^{64}$

Oczywiście najwięcej pensji żeńskich powstało w samej stolicy. W 1804 r. krytycznie oceniony został projekt nowej pensji pani Vaucher w Warszawie ${ }^{65}$. Jak stwierdzono, proponuje ona nazbyt klasztorny typ wychowania, nie posiada również odpowiedniej kadry nauczycielskiej do nadmiernie rozbudowanego, jak dla dziewcząt programu nauczania.

Regulamin Instytutu panny Vaucher, $1803 \mathrm{r}^{66}$

Godz. 6.00 Pobudka. Dziewczęta w ciszy udają się dwójkami na miejsce modlitwy.

Godz. 7.30 Śniadanie - zupa na piwie, kawa, herbata, coś ciepłego, jedna mała bułka. Po śniadaniu odpoczynek do 8.00.

Godz. 8.00 Recytacja lekcji gramatyki francuskiej i historii. Poprawienie opowiadania, listu i zadania domowego. Komentarze do historii i innych tematów.

Godz. 10.00 Drugie śniadanie. Biały chleb, masło, względnie coś innego, o co uczennice poproszą. Lekcja muzyki i rysunku, a te, które ich nie biorą, czytają lekturę i streszczenie.

${ }^{60}$ S. Litak, Z problemów edukacji dziewcząt w Polsce XVII-XVIII wieku, s. 51.

${ }^{61}$ A. Conrad, ,Jungfraw Schule“ und Christenlehre. Lutherische und katholische Elementarbildung für Mädchen, w: Geschichte der Mädchen-..., Bd. 1, s. 175.

${ }^{62}$ AGAD, GDPP, I 1613.

${ }^{63}$ Besondere Schul-Tabelle von den äußeren und inneren Zustande der katholischen Schulen, AGAD, GDPP, I 1613.

${ }^{64}$ Protokół wizytacji Gedikego, Łeczyca 21.06.1802, AGAD, GDPP, VI 1487, n.p.

${ }^{65}$ DPP do KWD w Warszawie, Berlin 6.05.1804, AGAD, GDPP, I 257, k. 202; KWD w Warszawie, Fischer do PDF, Warszawa 8.04.1804, AGAD, I 257, k. 203-205; wspomina ją F. Gajewski, Pamiętniki, T. 1, s. 18.

${ }^{66}$ AGAD, GDPP, I 257, k. 206-217. 
Godz. 11.00 Arytmetyka.

Godz. 11.45 Język niemiecki i polski.

Godz.12.30 Obiad - zupa inna każdego dnia, bulion, warzywa, względnie pieczywo, pieczeń, względnie potrawka z mięsa. Rodzice określają rodzaj chleba podawanego dzieciom i czy dawać wodę czystą czy z winem i piwo. Podczas obiadu rozmowy o gazetach, wiadomościach w mieście, bez podnoszenia głosu. Po obiedzie rekreacja, ale nie z tymi samymi koleżankami, a z wszystkimi. W wypadku kłótni należy zwrócić się do wychowawcy.

Godz. 14.00 Religia - Pismo Święte.

Godz. 14.45 - Język niemiecki i polski.

Godz. 16.00 - Geografia.

Godz. 17.00 Podwieczorek - biały chleb, owoce, względnie coś innego. Taniec - jeżeli uczennica nie bierze w nim udziału po kwadransie odpoczynku lekcja o narodzinach, postępie nauk i sztuk, pisanie listu na podany temat. Odpowiadanie na pytania zadane przez nauczycielkę. Odrabianie lekcji na dzień następny. Każda uczennica pisze swój dziennik, w którym odnotowuje swoje dobre uczynki, albo zaniechania w tym zakresie, znajomości które nabyła i zaniedbała.

Godz. 19.00 Kolacja - zupa z jajek, warzyw, kompot, pieczeń. Konwersacje jak przy śniadaniu. Rekreacja podobnie jak po obiedzie.

Godz. 20.45 Modlitwa i pójście spać.

Dni tygodnia:

Czwartek: wieczór czasem wolny, gdy nie będzie święta w tygodniu. Dzień wolny w lecie od 14.30 do 16.00, a w zimie od 17.00-18.30. Czas przeznaczony na powtórkę materiału z ostatnich dni. W razie opuszczenia lekcji nadrobienie ich właśnie wtedy. Spacer.

Piątek: powtórka materiału, pisanie wypracowania.

Sobota: Wieczór na podsumowanie we własnym dzienniczku, aby zdać sobie sprawę z postępów w nauce.

Niedziela: Msza o 8.00. Nauka ewangelii, katechizmu, czytanie na głos, kazanie. Podczas całego dnia czas na wypoczynek, jedynie $1 / 2$ godziny po południu na pobożną lekturę. Jeżeli ładna pogoda, spacer. Podczas posiłku miejsca przy stole rodzielane w ten sposób, że pierwsze (koło panny Vaucher) przydzielone uczennicy najbardziej rozumnej, kolejne dla zajmujących następne miejsca.

Rytm roczny:

Co miesiąc: wielka powtórka. Listy do rodziców i rodziny. Rodzice będą oceniali postępy dzieci na podstawie listów - listy nie będą poprawiane przez szkołę, chyba, że rodzice zadecydują inaczej.

Co trzy miesiące: raport dla rodziców o postępach dzieci.

Co cztery miesiące: generalna powtórka, przyjęcie sakramentów, koniecznie na Wielkanoc, Wniebowstąpienie, Boże Narodzenie, a jeżeli spowiednik uzna za stosowne, częściej. Czytanie regulaminu szkoły: 
Corocznie: Publiczny pokaz lekcji - egzamin z rodzicami, którzy będą w ten sposób mieli udział w sukcesie swoich dzieci. Oszczędność wchodzi w skład planu edukacji, będzie się do niej przykładać wagę we wszystkich klasach. Nie będzie wyznaczonego lekarza szkolnego - rodzice wskażą tego, wobec którego mają zaufanie, tak samo w przypadku nauczycieli muzyki, tańca, rysunku. Uczennice nie będą wychodzić z nikim bez pisemnego zezwolenia rodziców. Panna Vaucher śpi w tym samym budynku, co uczennice i odpowiada za powierzone jej dobra materialne. Opłata roczna wynosi 100 dukatów płatna w dwóch ratach albo w całości. Dodatkowo 6 dukatów jednorazowo na książki, sztućce, serwetki.

W departamencie poznańskim pensje koncentrowały się przede wszystkim w Poznaniu. Po 1793 r. do prowincji zaczęły ściągać kobiety z Prus, usiłując znaleźć tu zarobek przez założenie pensji dla dziewcząt. Tak było w wypadku wdowy po kapitanie pruskim, pochodzącej z Wrocławia Anny von Drevitz ${ }^{67}$, która skierowała do Hoyma prośbę o zgodę na otwarcie pensji żeńskiej w Poznaniu, a wcześniej taką pensję prowadziła we Wrocławiu. Po pięciu tygodniach pobytu w Poznaniu udało się jej pozyskać tylko trzy uczennice i zabiegała o finansowe wsparcie dla swego przedsięwzięcia prosząc o $25 \mathrm{rtl}$. pensji, wolne drewno na opał i bezpłatny lokal na szkołę ${ }^{68}$. Kamera poznańska poparła jej starania, stwierdzając, że w Poznaniu szkoły żeńskiej brakuje. Hoym wyraził zgodę na przyznanie jej żądanej pensji oraz drewna na opał, starania o lokal na szkołę jednak odrzucił $^{69}$. Anna Drevitz przedstawiając swoje zamiary, stwierdziła, że zamierza utworzyć szkołę trzyklasową ${ }^{70}$. W klasie pierwszej miano by nauczać dziewczęta sylabizowania i podstaw chrześcijaństwa. Program klasy drugiej miał obejmować czytanie i pisanie w języku niemieckim, język francuski, historię naturalną, geografię, epistolografię i szycie. W klasie trzeciej dołączyć do tego miały zajęcia z rysunku, malarstwa, muzyki, szycia i języka polskiego. Lekcje trwać miały od godziny 6 do 12 przed południem i od 14 do 16 po południu. Czesne wynosić miało w klasie pierwszej $1 \mathrm{rtl}$., w drugiej 2 rtl. i 3 rtl. w trzeciej klasie. Pensja przeznaczona była dla dziewcząt niemieckich. Godne uwagi, że za konieczne uważano uczenie ich języka polskiego. Już 18 września 1798 r. pensja Drevitz została wysoko oceniona przez komisję złożoną z miejscowego seniora Stechebahra i 11 rodziców ${ }^{71}$. Według sprawozdania Kasjusza z 25 lipca 1798 r. ${ }^{72}$ do placówki prowadzonej przez wdowę uczęszczało 11 dziewcząt zarówno szlachcianek, jak i mieszczanek, które płaciły 28 rtl. czesnego. Miała ona swym poziomem przewyższać wszystkie poznańskie szkoły protestanckie. Drevitz zatrudniała do pomocy nauczycielkę języka niemieckiego i rysunków oraz do prowadzenia zajeć z prac kobiecych.

\footnotetext{
${ }^{67}$ Kapitanowa Anna Johanna von Drevitz do Hoyma, Wrocław 2.09.1797, AGAD, I 257, k. 5-6.

${ }^{68}$ KWD w Poznaniu do Hoyma, Poznań 7.01.1798, AGAD, I 257, k. 27-28.

${ }^{69}$ Hoym do KWD w Poznaniu, 25.01.1798, AGAD, GDPP, I 257, k. 32.

${ }^{70}$ Anna Johanna Drevitz, Posen 12.12.1797, AGAD, GDPP, I 257, k. 29-31.

${ }^{71}$ KWD w Poznaniu do DPP, Posen 18.09.1798, AGAD, I 257, k. 60-61.

${ }^{72}$ Casius, Sprawozdanie o stanie pensji Drevitz, Poznań 25.07.1798, AGAD, GDPP, I 257, k. 68-71.
} 
Jeszcze w 1798 r. z wnioskiem o wsparcie prywatnej szkoły żeńskiej w Poznaniu wystąpiła Louise Tusch ${ }^{73}$. Wcześniej była ona guwernantką hrabiego Grudzińskiego w Chodzieży ${ }^{74}$. Jej starania ocenione zostały pozytywnie przez kamerę poznańską, która zalecała, aby przyznać jej od państwa 80-100 rtl. na wynajęcie mieszkania. Tusch, oprócz prac kobiecych uczyć miała pisania, obyczajów i charakteru, muzyki, religii, języka francuskiego i rachunków. Przewidywała zatrudnienie do pomocy nauczyciela ${ }^{75}$. Według sprawozdania z sierpnia 1798 r. do szkoły Tusch uczęszczało 7 szlachcianek i 12 mieszczanek i otrzymywały edukację w zakresie języka niemieckiego, francuskiego, rachunków, historii naturalnej, szycia i rysunków. Jeszcze przed 1800 r. Louise Tusch zmarła i jej pensja została zlikwidowana ${ }^{76}$. Wówczas jedyną pensją żeńską w Poznaniu pozostawał rzekomo zakład wdowy Drevitz. Mimo to jej prowadząca cierpiała nieustannie na brak pieniędzy i bombardowała kamerę poznańską częściowo skutecznymi prośbami o wsparcie, przede wszystkim tytułem pokrycia kosztów wynajmu lokalu. W $1800 \mathrm{r}$. kamera zaproponowała departamentowi przyznanie jej stałej pensji w wysokości $100 \mathrm{rtl}$, jednak ten z braku środków zgodził się tylko na jednorazową zapomogę w wysokości $50 \mathrm{rtl}^{.77}$

Sukcesy Drevitz w wyciąganiu pieniędzy z państwowej kieszeni dotarły do Wrocławia i w 1800 r. do rąk Vossa trafiła prośba innej wdowy wrocławskiej, pułkownikowej Lindenfels, która bez ogórdek pisała, że chciałaby dostać z departamentu podobną dotację, jak Drevitz ${ }^{78}$. Powoływała się na zasługi męża, który odbywał służbę garnizonową w Warszawie i zmarł przed trzema laty, pozostawiając ją w marnym położeniu materialnym (otrzymywała po mężu 100 rtl. emerytury). Jako na kwalifikacje do prowadzenia szkoły wskazywała na „dobre wychowanie, jakie otrzymała od rodziców”, dodając, że wychowywanie dzieci jest jej „ulubionym zajęciem”.

Okazało się, że kasa państwowa nie jest rozciągliwa i departament ocenił, że jego możliwości wspierania prywatnych pensji uległy wyczerpaniu. Przy tej okazji usiłowano zresztą pomniejszyć wrażenie dotacji, jakie otrzymała Drevitz ${ }^{79}$. Lindenfels nie opuściła jednak rąk i w 1802 r. donosiła już z Rawy w Prusach Południowych, że zamierza tam założyć pensję dla córek szlacheckich, co spotkało się z dużym zainteresowaniem okolicznych posesjonatów ${ }^{80}$.

\footnotetext{
${ }^{73}$ Voß do KWD w Poznaniu, Poznań 24.06.1798, AGAD, GDPP, I 257, k.54.

${ }^{74}$ Cassius, Sprawozdanie o pensji wdowy Tusch, Poznań, 1.08.1798, AGAD, GDPP 257, k. 75-77.

75 KWD w Poznaniu do DPP, Poznań 20.09.1798, AGAD, GDPP, I 257, k. 72-74.

${ }^{76}$ Drewitz do Voßa, Posen 7.05.1800, AGAD, I 257, k. 142-143.

77 KWD w Poznaniu do DPP, Poznań 10.06.1800, AGAD, GDPP, I 257, k. 145-146; DPP do KWD w Poznaniu, Berlin 26.06.1800 r., AGAD, I 257, k. 147.

78 Wdowa pułkownikowa Lindenfels do Vossa, Wrocław 7.09.1800, AGAD, GDPP, I 257, k. 154-155.

79 Klewitz do Lindenfels, Berlin 16.09.1800, AGAD, I 257, k. 156.

${ }^{80}$ Wdowa Lindenfels do Vossa, Rawa 13.07.1802, AGAD, I 257, k. 175-176.
} 
Również dzięki załatwionemu odmownie wnioskowi o wsparcie z państwowej kiesy z 1802 r., wiemy o istnieniu poznańskiej pensji żeńskiej Christiny Rauer ${ }^{81}$. Prowadziła ona swoją placówkę od 1798 r. Uczęszczały do niej córki mieszczańskie oraz 6-10 szlachcianek. Rauer prowadziła lekcje z języka niemieckiego, francuskiego oraz prac kobiecych: szycia, robienia na drutach i łatania. Jak donosiła Rauer, większość uczennic stanowiły Polki, które przychodząc na pensję, nie znały ani słowa po niemiecku. Musiały opłacać czesne wynoszące 2 rtl. od osoby, a Rauer zatrudniała pomocniczą nauczycielkę, której płaciła 12 rtl. miesięcznie.

W Poznaniu nie było jednak pełnego zadowolenia $\mathrm{z}$ istniejących pensji żeńskich, jako że w 1805 r. kilka pań wystosowało do władz prośbę o założenie publicznej żeńskiej szkoły. Jak uważały państwo powinno zwracać uwagę nie tylko na edukację chłopców, ale zająć się również edukacją dziewcząt, doceniając w ten sposób doniosłą rolę tej płci w społeczeństwie. Jak twierdziły, brak takiej szkoły odczuwają kobiety w całej prowincji. ${ }^{82}$ Nauczycielki-emigrantki i lokalne guwernerki uznały istniejące pensje za zupełnie niespełniające ich oczekiwania wychowawcze i jak sądziły, jedyne co im pozostaje, to wysyłanie córek na naukę za granicę.

Na pismo pań poznańskich odpowiedziała kamera wojenna i domenalna w następujący sposób ${ }^{83}$ : w żadnej prowincji pruskiej państwo nie zajmuje się szkolnictwem żeńskim powyżej poziomu elementarnego, ponieważ brakuje na to środków, które są wydatkowane na „ogólne potrzeby szkolne”. Zakładanie szkół żeńskich należy wszędzie do inicjatyw prywatnych, które są przez władze państwowe popierane.

$\mathrm{W}$ departamencie poznańskim poza jego miastem stołecznym funkcjonowały z pewnością i placówki w mniejszych miejscowościach. Ze źródeł pruskich dociera do nas informacja o Zdunach, gdzie znalazła się kapitanowa Idea von Hülsen, która dokonała rekonesansu wśród miejscowej szlachty i znalazła wielu chętnych do nauczania języka niemieckiego i robót kobiecych ${ }^{84}$. Jej pracom przeciwstawiał się miejscowy nauczyciel, który zamierzał pozyskać szlachcianki do swojej szkoły miejskiej. Władze pruskie uznały jednak ten pomysł za chybiony i zgodziły się na działalność pensji Hülsen ${ }^{85}$.

Osobliwością była szkoła żeńska prowadzona w Kaliszu przez pastora Sienela od $1802^{86}$. Jego uczennicami były córki urzędników i kaliskiego patrycjatu. Uczył je ,wiedzy koniecznej płci niewieściej” oraz języka francuskiego i rysunków. Był to jedyny występujący w źródłach przypadek, gdy szkołę żeńską prowadził mężczyzna.

Obraz edukacji niższej kobiet na ziemiach polskich do 1793 r. jest zupełnie mętny. Wizytacje kościelne z XVII w. nie informowały w ogóle, czy w danej placówce uczą się

${ }^{81}$ Wdowa Christina Rauer do Voßa, Poznań 11.06.1802, AGAD, GDPP, I 257, k. 171-173; DPP do Rauer, Poznań 13.06.1802, AGAD, GDPP, I 257, k. 174.

${ }^{82}$ Franciszka Flesche, Charlotta Witte, Amalie Lesemann, Maria Stremler, Adelgonde de Tolkmit, Konstancja Graboszewska i in. do Voßa, Poznań 19.06.1805, AGAD, I 257, k. 248-250.

${ }^{83}$ KWD w Poznaniu do Pań...(j.w.), Poznań 20.06.1804, AGAD, GDPP, I 257, k. 251.

${ }^{84}$ Kapitanowa Idea von Hulsen do Voßa, Zduny 1.02.1804, AGAD, GDPP, I 257, k. 198.

${ }^{85}$ KWD w Poznaniu, Strachwitz do DPP, Posen 19.06.1804, AGAD, GDPP, I 257, k. 229-231.

${ }^{86}$ Pastor Sienel do Voßa, Kalisz 2.05.1805, AGAD, GDPP, I 257, k. 243-246. 
dziewczęta i można to wywnioskować tylko z informacji pośrednich, np. z zalecenia, aby dziewczęta nie uczyły się w jednej izbie z chłopcami ${ }^{87}$. Generalnie jednak Stanisław Olczak doszedł do wniosku, że nieco częściej dziewczęta zaczęły się pokazywać w szkołach dopiero w drugiej połowie XVIII w. Na przykład na 53 szkoły części dekanatu śremskiego w 1777 r. w 17\% szkół uczyły się również dziewczęta. W wielkopolskiej części diecezji poznańskiej wzmianki o nauczaniu dziewcząt pojawiają się w 63 szkołach na 163, tj. w 43\%. Zapisom towarzyszyły czasem nierealne zalecenia, aby dziewcząt nauczały pobożne kobiety ${ }^{88}$. Stanisław Litak ${ }^{89}$ stwierdził, że w Małopolsce w połowie XVIII w. na 108 szkół, w wypadku których podano informacje o płci uczniów, dziewczęta uczęszczały do 4 i do powstania KEN dziewczynki do szkół nie chodziły, podczas gdy na będącej pod niemieckim wpływem Warmii już od XVI w. Podobnie w Prusach Królewskich, zwłaszcza po 1772 r. zdarzało się to częściej. Poza tym jednak w Małopolsce w 1792 r. wskaźnik ten wzrósł do 26\%. Stanisław Litak twierdzi też, że w Wielkopolsce edukacja szkolna dziewcząt była częstsza.

Wiadomo, że KEN podejmowała wysiłki, aby zwiększyć udział dziewcząt w nauce elementarnej, którą uważano za stosowną do ich płci. Michał Marian Grzybowski pokazuje niestety na jednostkowych przykładach, że na Mazowszu Północnym w dobie KEN dziewczęta uczono razem z chłopcami ${ }^{90}$. W dobie Królestwa Kongresowego w szkołach biskupstwa płockiego nadal występowała przytłaczająca przewaga chłopców ${ }^{91}$. Na Litwie na początku XIX w. dziewczęta w szkołach niższych pozostały zjawiskiem rzadkim. W 1807 r. na 5297 chłopców przypadało w nich 580 dziewcząt ${ }^{92}$.

Radykalnie odmiennie przedstawiała się sytuacja w Prusach, gdzie edukacja elementarna dziewcząt była względnie powszechna i dziewczęta objęte były obowiązkiem szkolnym $^{93}$. Być może należy to wiązać z charakterem protestantyzmu, który przykładał dużą wagę do lektury Pisma Świętego przez wiernych. Należy jednak zwrócić uwagę, że obowiązek szkolny dla dziewcząt wprowadzono w 1774 r. również w katolickiej Austrii ${ }^{94}$, co wskazuje na wspólny dla oświecenia model zabiegów o danie matkom pewnego zasobu wiedzy potrzebnego do kształtowania przyszłych poddanych.

W Prusach Południowych tylko dla szkół protestanckich otrzymujemy informacje o uczęszczających do nich dziewczętach (Tabellen von den saemtlichen evangelischen Schulen in Südpreußen). Wynika z nich jednoznacznie, że do tych szkół elementarnych

${ }^{87}$ Chamcówna M., Szkolnictwo wiejskie, s. 486.

${ }^{88}$ S. Olczak, Szkolnictwo parafialne w Wielkopolsce w XVII i XVIII wieku, Lublin 1978, s. 123-126; por. A. Zapart, Szkolnictwo parafialne w archidiakonacie krakowskim od XVI do XVIII wieku, Lublin 1983 s. 255.

${ }^{89}$ S. Litak, Struktura i funkcje parafii w Polsce, w: Kościót w Polsce, red. Jerzy Kłoczowski, Lublin 1971, T. 2, s. 413-414, 419. S. Litak, Edukacja początkowa w polskich szkołach..., s. 192-199.

${ }_{90}$ M.M. Grzybowski, Szkolnictwo elementarne na Mazowszu Pótnocnym na przełomie XVIII $i$ XIX w. w świetle wizytacji kościelnych (1764-1830), Płock 1987, s. 19.

${ }^{9}$ Ibidem, s. 137-139; por. R. Pelczar, Szkolnictwo w miastach zachodnich ziem województwa ruskiego (XVI-XVIII w.), Lublin 1991, s. 60.

${ }^{92}$ D. Beauvois, Szkolnictwo polskie na ziemiach litewsko-ruskich 1803-1832, Lublin 1991, t. 2, s. 399-400.

93 W. Neugebauer, Absolutistischer Staat..., s. 619-620.

94 G. Grimm, Expansion, Uniformisierung, Disziplinierung, Revolution des Wissens, s. 243. 
dziewczęta uczęszczały w takim samym stopniu, jak chłopcy (np. w szkole miejskiej w Międzyrzeczu na 159 chłopców przypadało 170 dziewcząt, w Babimoście na 52 chłopców 60 dziewcząt). Podczas swojej podróży wizytacyjnej w 1800 r. Meierotto wysoko ocenił trzyklasową szkołę dla dziewcząt w Bojanowie. Na pierwszym miejscu jego uwagę zwróciła czystość dziewcząt, ich stosowny przyodziewek, skromna przyzwoitość zachowania i szczerość. Uczyły się one religii, ortografii, podstaw języka niemieckiego, rachunków z liczeniem w pamięci włącznie i języka polskiego ${ }^{95}$. Odrębne oddziały dla dziewcząt istniały również przy szkołach dla chłopców. Taką szkołę powołali benonici w Warszawie. Uczono tam czytania, pisania, szycia i robienia na drutach ${ }^{96}$. Dziewczęta uczęszczać też miały do szkół obywatelskich i garnizonowych. Z całą pewnością było tak w Piotrkowie, gdzie wśród uczennic znajdujemy córki wojskowych i urzędników ${ }^{97}$.

Rozproszone informacje wskazują, że do szkół uczęszczały czasami również dziewczęta katolickie. W dekanacie zbąskim, gdzie występowała znaczna liczba Niemców katolików, na uczących się w 26 szkołach 496 chłopców przypadało 328 dziewcząt ${ }^{98}$.

Zarówno w wypadku szkół mieszczańskich, jak i wojskowych pojawił się postulat zatrudnienia jako nauczycielki dziewcząt kobiety. Ze względów praktycznych była to $\mathrm{z}$ reguły żona nauczyciela, która otrzymywała uposażenie o połowę niższe od nauczyciela, albo i jeszcze skromniejsze. W Izbicy żona nauczyciela dostawała 25 rtl. pensji, co stanowiło $1 / 4$ wynagrodzenia jej męża ${ }^{99}$. W Pabianicach nauczyciel miał otrzymywać $120 \mathrm{rtl}$., natomiast jego żona ucząca dziewcząt $24 \mathrm{rtt} .{ }^{100}$ Nie musiała też mieć żadnych kwalifikacji zawodowych, bo uczyła dziewczęta jedynie prac „kobiecych”

Generalnie była to sytuacja nowa. Do drugiej połowy XVIII w. pewną trwałość zachował postulat bezżenności nauczycieli, którzy nawet w wypadku nauczycieli szkół elementarnych występować mieli $\mathrm{w}$ stroju półduchownym ${ }^{102}$. Z drugiej strony wiemy, że kobiety występowały jako nauczycielki w szkołach pokątnych dla dziewcząt. W $1793 \mathrm{r}$. w Lesznie odnotowana była Susanna Elisabeth Handke jako nauczycielka prowadząca szkołę elementarną. Fakt prowadzenia szkoły przez kobietę uznany jednak został przez urzędników pruskich za przejaw kryzysu ${ }^{103}$.

Pomysł zatrudniania żony nauczyciela jako nauczycielki dla dziewcząt nie został jednak przyniesiony z Prus. Już Ignacy Krasicki w Panu Podstolim pokazywał to rozwiązanie jako wzorcowe: Żona bakałarza uczy dziewczatka nie tylko pisać, czytać, ale i robót

95 P. Schwartz, Die preußische Schulpolitik, s. 174.

96 Ibidem, s. 181.

${ }^{97}$ Protokół Gedikego z wizytacji w szkole w Piotrkowie, Piotrków 7.07.1802, AGAD, GDPP, VI 2067, k. 1-2.

98 AA w Poznaniu, KA M 023

${ }^{99}$ KWD w Poznaniu do PDF, Poznań 8.10.1805 r., AGAD, GDPP, VI 837, k. 1-4.

${ }^{100}$ Werdermann do PDF, Kalisz 22.09.1805, AGAD, GDPP, VI 1981, n.p.

101 np. KWD w Warszawie do PDF, Warszawa 3.03.1801 r., AGAD, GDPP, VI 133, s. 19-20.

102 S. Olczak, s. 104.

${ }^{103}$ General-Senior Klose, Verzeichniss der Evangelisch-Reformirten Schulen in Süd-Preussen, Lissa, 14 czerwca 1793 r., Das Jahr 1793, s. 695. 
[...] gdy który z chłopców wiejskich nadzwyczajna ma bystrość, oddawać go każe do wyższych szkót; sposobni do roboty ucza się rzemiost $t^{104}$. Oznaczało to, że bezżenność nauczycieli przestała być bezwzględnym nakazem. Tak też w projekcie ustawy dla szkół parafialnych z 1781 r. rzecz widział Kazimierz Narbutt, który uważał za wskazane zatrudnianie „mistrzyń” dla nauczania dziewcząt ${ }^{105}$, podobnie za zatrudnianiem nauczycielek opowiadał się Ignacy Krasicki ${ }^{106}$.

Na konieczność edukacji dziewcząt przez nauczycielki wskazywał Grzegorz Piramowicz, poświęcając w swej książce $O$ powinnościach nauczyciela, osobny rozdział „mistrzyniom płci niewieściej”107. Jeżeli Piramowicz pisał o „mistrzyniach płci niewieściej”, to w czasach Rzeczypospolitej nauczycielki określano też, jako „pobożne kobiety”. W czasach płudniowopruskich Józef Jeziorowski pisał, że nauczycielką powinna zostać „osoba płci niewieściej” (weibliche Person) ${ }^{108}$, najlepiej żona nauczyciela. Nie ma mowy o jakichkolwiek kwalifikacjach, które musiałaby posiadać. Miała mieć „,kwalifikacje kobiety", a więc umieć szyć, cerować, robić na drutach, gotować i prać.

\section{Zakończenie}

Epoka Oświecenia zapoczątkowała znaczące zmiany w formach, zakresie oraz masowości kształcenia dziewcząt. O ile w krajach protestanckich dziewczęta od dawna objęte były edukacją elementarną, o tyle obecnie stopniowo rozszerzało się to na kraje katolickie, obejmując warstwy uboższe w skali coraz bardziej masowej. Trwały charakter miały tradycyjne formy edukacji panien, czyli nauka klasztorna i nauczyciele domowi, właściwe przede wszystkim dla zamożniejszych. Stopniowo rozwijały się też szkoły i pensje dla dziewcząt w miastach. Podstawowa forma przyuczania do ról życiowych, przede wszystkim żony i matki, nadal odbywała się jednak w domu, przez naśladowanie matki. Musimy pamiętać, że oznaczało to również współpracę z mężem w pracach gospodarczych jako że trwałość zachowywała jedność rodziny i miejsca pracy, rozbita dopiero przez industrializację. Decydujące o równouprawnieniu zmiany, czyli rozwój masowego szkolnictwa średniego o programie uniwersalnym i studia wyższe dla dziewcząt, należały jeszcze do odległej przyszłości. Tymczasem ,szkoły dla córek” znaczną część programu poświęcały religii, pracom kobiecym, muzyce i właściwej dla salonów nauce języka francuskiego. Obecność pruska na ziemiach polskich nieco przyśpieszyła modernizację szkolnictwa żeńskiego, nie był to też jeszcze etap budzącej sprzeciw forsownej germanizacji.

104 T. Wierzbowski, Szkoty parafialne w Polsce i na Litwie za czasów KEN (1772-1793), Kraków 1922, s. 19.

105 A. Pohoska A., Sprawa oświaty ludu w dobie KEN, Kraków 1925, s. 105-106.

106 I. Krasicki, Pan Podstoli, Kraków 1927 (1778), s. 245.

107 G. Piramowicz, O powinnościach nauczyciela, Warszawa 1959, s. 105.

108 Próba planu organizacji trzech seminariów dla szkół wiejskich i niższych szkół miejskich w Prusach Południowych, 22.02.1804 r., AGAD, GDPP, I 1640, k. 102-106. 